\title{
Indian Buddhist Attitudes toward Outcastes
}

Rhetoric around caṇḍālas

\author{
Jonathan A. Silk \\ Leiden University, Leiden, The Netherlands \\ J.A.Silk@hum.leidenuniv.nl
}

\begin{abstract}
Indian Buddhist literary sources contain both systematic and casual rejections of, broadly speaking, the caste system and caste discrimination. However, they also provide ample evidence for, possibly subconscious, discriminatory attitudes toward outcastes, prototypically cand $\bar{a}$ las. The rhetoric found in Indian Buddhist literature regarding caṇ̂ălas is examined in this paper.
\end{abstract}

\section{Keywords}

caṇdāla - caste - Buddhism - prejudice - ancient India - discrimination

\section{General Issues}

Much attention has been devoted both from scholarly and other points of view to the proposition that the Buddha (and implicitly Indian Buddhism tout court) propounded an anti-caste ideology. ${ }^{1}$ Since I believe that we know precisely nothing about the Buddha as an individual, and moreover since serious questions may be raised about the earliest situation of Buddhism in India, ${ }^{2}$ I am

1 There is no point to offer a bibliography here, but see for instance Chalmers 1894; Law 1937: 11-26; Barua 1959; Fujita 1953; Ellis 2019. The topic of caṇ̂ălas in Indian Buddhism has also not been ignored; see for instance esp. Miyasaka 1991, 1992, 1993, 1994, 1995a; Ujike 1985.

2 I refer particularly to the questions raised by Johannes Bronkhorst (for a brief summary see Bronkhorst Forthcoming) about the unlikelihood of actual contact at the time of the Buddha between brahmanical communities and the region where the Buddha is held to have lived. Bronkhorst argues that there was, at the time of the Buddha, a cultural divide between the 
content in the following to understand all claims made about "the Buddha" to refer to the statements found in Indian Buddhist literature (of all periods), and in this respect, despite the wide chronological and doubtless also geographical range of their composition, we find there a largely consistent rejection of the validity (though not the social reality) of the caste system. The present study, being devoted to ideology and rhetoric, will therefore largely set aside questions about how and indeed even if such rhetoric was actualized in the daily life of Indian Buddhists or Indian Buddhist communities (a question concerning which, on the whole, we lack good evidence). Where we do have ample evidence is in regard to textual expressions, through which, I maintain, we can detect reflections of the attitudes of their authors. These then, rather than any actual socially embedded situation, form the central focus of this study. However, in the conclusion I will dare to offer some speculations about what relation there might be between attitudes and actions.

While there is a broad unanimity of opinion regarding at least Buddhist rhetorical attitudes toward the caste system (however that is understood, and keeping in mind that it was historically much less a "system" than it might now generally appear), those outside the four primary hierarchical divisions (varṇa) — the brāhmaṇas, kṣatriyas, vaiśyas and śūdras-have drawn less attention, and it is with this (real or imagined) group that the present remarks are centrally concerned. In order to provide a context, however, it is necessary to begin with a brief look at Indian Buddhist textual attitudes toward caste, and some of their complications, before we turn to the outcastes. Given that the survey of attitudes toward caste is well-trodden ground, there may be found here little that is new. ${ }^{3}$

brahmanical west and Greater Magadha, the heartland of Buddhism. Therefore, while half of this equation leads to the conclusion that the non-brahmanical east was the source of a number of notions later integrated completely into the brahmanical world-view, the correlate is that at the time of the Buddha, the east being as yet unbrahmanized, the Buddha (and others) could not have been responding (directly) to brahmanical ideas, practices or cultural and social structures. With regard specifically to caste, the implication is that it was simply not present in the form we see later, and of course much earlier but — and this is key—only in the Vedic-brahmanical west, not in Greater Magadha. A conclusion to be drawn is that the Buddha and earlier Buddhism was not responding to a social situation which, in their domain, did not yet exist. If correct, his hypotheses would imply the unlikelihood of brahmanical caste structures being an object of concern for the Buddha. However, even if they were not, they did certainly become so later for Buddhist communities, and this is my concern here.

3 The same may be true even for the second part of this essay, at least in terms of overall understanding. Already Jha 1975: 28 could write (after observing that Buddhist sources are more severe than brahmanical ones regarding the rathakāra, on which see below), "In vain does one look to Buddhism for an effectively different attitude to caste and its most unseemly offshoot, the institution of untouchability, for it developed its own set of intensely prized 
A number of passages are routinely cited as evidence that Indian Buddhism rejects caste hierarchies. For instance, the Majjhimanikāya maintains that while two castes, the kṣatriyas and brāhmanas, are normally treated as superior, from the point of view of liberation all four castes are equivalent. ${ }^{4}$ The Anguttaranikāya for its part holds that one of the prophetic dreams through which the bodhisatta Siddhattha realized his coming awakening spoke in fact of caste equality: ${ }^{5}$

taboos, besides those it shared with brāhmaṇism." It should be noted in passing that Jha on the whole restricts his attention to Päli sources. It might also be noted that Jha repeatedly seeks to explain Buddhist negative attitudes toward low-caste marginals by associating their activities with those ideologically objectionable to Buddhists. Thus leather workers were "connected with the flaying of cattle," and cartwrights "simply because they built chariots for war which it [Buddhism-JAs] hated," (Jha 1979: 102), while "Presumably, in keeping with the traditional profession of the Baindas [an aboriginal tribe-JAs] the Venas [bamboo workersJAs] continued as hunters, and as such incurred the antipathy of the Buddhist writers" (Jha 1978: 231). These assertions (or at best suggestions) of a sort of rational cause coherent with Buddhist doctrine seem to me entirely ad hoc and unprovable. Moreover, they seem contradicted by the kinds of evidence we do see, most particularly in the case of the paradigmatic marginals, the candūa las. An additional crucial point here is made clearly by Eltschinger 2012: 157: "To say that Indian Buddhism never was abolitionist [with regard to caste-JAs] moreover immediately requires an important nuance. For while it does not deny, nor hopes to abolish, the presence of statutory designations in the world, Indian Buddhism is, in theory and perhaps also in fact, uniformly abolitionist in its soteriology."

It should perhaps be emphasized here at the outset that I have no aspirations to completeness, and know of many interesting materials which I simply could not include, and doubtless there is much more of which I am simply unaware. Thus, I do not notice here stories in which candâlas may play even a central role, if I do not find that their status as candālas is informative for the discussion here; as as example, see the story from the Samghabhedavastu of the Mūlasarvāstivāda Vinaya translated and discussed by Davidson 2017: 20-23. In view of these limitations, I take solace in the fact that Dr. Haiyan Hu-von Hinüber has kindly informed me of her plan to research the topic in detail, and I have little doubt that her investigations will prove much more exhaustive than my own.

A final additional point is that my aim here is to look exclusively at Indian materials. It would be a fascinating study to examine how culturally specific Indian ideas found an afterlife in, for instance, China and beyond in East Asia. At its perhaps most extreme, we find a total domestication of the notion of candāla in Japan, where the sendara 斿陀羅 = eta 穢 多 = hinin 非人 (terms more recently replaced by burakumin 部落人) status was broadly accepted, and persists even until today. Among the very extensive literature, little of which is scholarly, however, see Vollmer 1994; Bodiford 1996; Hayashi 1997. Regarding monastic ordination of low status individuals in Tibet, see Jansen 2014.

4 MN ii.128,2-8; ii.129,27-28. See also T. 26 (22) (I) 793c11-17; D 1, 'dul ba, kha, 88b3-5.

5 AN iii.242,14-22: yam pi bhikkhave tathägatassa arahato sammāsambuddhassa pubbeva sambodhā anabhisambuddhassa bodhisattasseva sato cattāro sakuṇā nānāvaṇnā catūhi disāhi 
When the Tathāgata, the Arahant, the Perfectly Enlightened One-before his enlightenment, while just a bodhisatta, not fully enlightened[dreamt] that four birds of different colors (vanna) came from the four quarters, fell at his feet, and turned all white, [this was a foretoken] that members of the four classes (vanna) — khattiyas, brahmins, vessas, and suddas - would go forth from the household life into homelessness in the Dhamma and discipline proclaimed by the Tathāgata and realize unsurpassed liberation. This fourth great dream appeared to him [as a sign] that his awakening [was imminent].

The late canonical Apadāna poetically repeats a passage found earlier in the Vinaya and Sutta, ${ }^{6}$ and speaks of the subsequent post-ordination non-differentiation of persons from the four castes, asserting that once they have renounced the world into the Buddha's community, all persons are equal: ${ }^{7}$

The rivers Sindu and Sarasvatī, Candabhāgā, Gangā and Yamunā, Sarabhū and then MahīThe ocean receives these as they flow into it. They give up their former name, and are all known [only] as the Ocean.

$\bar{a}$ gantvā pādamūle nipatitvā sabbasetā sampajjimsu cattāro me bhikkhave vannāa khattiyā brāhmañā vessā suddā te tathāgatappavedite dhammavinaye agārasmā anagāriyam pabbajitvā anuttaram vimuttim sacchikaronti | tassa abhisambodhāya ayam catuttho mahāsupino pāturahosi. Trans. Bodhi 2012: 814-815.

6 Vin ii.239,14-21: seyyathāpibhikkhaveyā kācimahānadiyo seyyath'idà̇|gañgāyamunāaciravatī sarabhū mahì tā mahāsamuddam pattā jahanti purimāni nāmagottāni mahāsamuddo tv eva sañkham gacchanti | evam eva kho bhikkhave cattāro' me vaṇnā | khattiyā brāhmaṇa vessā suddā. te tathāgatappavedite dhammavinaye agārasmā anagāriyam pabbajitvā jahanti purimāni nāmagottāni samaṇā sakyaputtiyā tv eva saìkham gacchanti. Trans. Horner 1938-1966: 5.334: "And even, monks, as those great rivers, that is to say the Ganges, the Jumna, the Aciravatī, the Sarabhū, the Mahī which, on reaching the great ocean, lose their former names and identities and are reckoned simply as the great ocean, even so, monks, (members of) these four castes: noble, brahmin, merchant and low, having gone forth from home into homelessness in this dhamma and discipline proclaimed by the Truth-finder, lose their former names and clans and are reckoned simply as recluses, sons of the Sakyans." See also AN iv.202,7-14.

$7 \quad 316-318=3 \cdot 1.177-179$ :

sindhū sarasvatī c'eva nadiyā candabhāgiyo | gañgā ca yamunā c'eva sarabhū ca atho mahī etāsaṁ sandamānānaṁ sāgaro sampațicchati | jahanti purimaìn nāmaìn sāgaro te’va ñāyati $\|$ tath' ev'ime catuvaṇnā pabbajitvā tav' antike | jahanti purimaì nāmam buddhaputtā ti ñāyare \|

Compare the trans. of Jonathan S. Walters http://apadanatranslation.org/text/chapter-3/poe m-oo1.html. 
In just the same way these persons of four castes, having gone forth before you [Buddha],

Give up their former name, and are known as "Sons of the Buddha."

Such ideas are by no means limited to the Pāli literature. In the Kunầlāvadāna (found within the Divyāvadāna), we encounter Aśoka's minister Yaśas, characterized as highly devoted to the Lord (paramaśräddho bhagavati), who nonetheless finds the king's behavior of prostrating himself at the feet of Buddhist monks whenever he saw them ${ }^{8}$ improper, and he says: 9 "Your Majesty, it is not proper that you bow down to renunciants who come from all castes. And indeed, the Buddhist novices (śrämaṇeraka) have renounced from all four castes." A few lines below we find several verses in which the king in return addresses Yaśas: 10

Sir, you consider caste, but not the good qualities which inhere in the Buddhist monks. Thus, sir, out of pride and arrogance about caste you harm both yourself and others out of ignorance. Now, at the time of a wedding, a marriage, one [rightly] considers caste, but not at the time of [teaching] the Dharma. For the causes of the practice of the Teaching are good

8 yatra śākyaputrīyān dadarśa ākīrṇe rahasi vā tatra śirasā pādayor nipatya vandate sma.

9 deva nārhasi sarvavarṇapravrajitānām praṇipātam kartum | santi hi śākyaśrāmaṇerakāś caturbhyo varnebhyah pravrajitā iti. Mukhopadhyaya 1963: 71.5-8, Cowell and Neil 1886: $382.5^{-10}$. A reviewer of the paper points to the apparently conflation here of śrämaneraka and śramana.

We might simply note here another narrative reference to the same idea. In the Kalpanāmaṇditikā, a man asks Śāriputra to ordain him, but the latter, finding no roots of good from previous lives in the man, refuses, as do the other monks. The man refused ordination stands before the monastery gates and cries, complaining: "Persons from all four castes are offered renunciation, what evil have I done that you do not offer it to me?" T. 201 (IV) 311c11-12: 四種姓中皆得出家。我造何惡, 獨不見度. (See also Huber 1908: 284). The man then utters a stanza, the beginning of which runs, "As pure water is offered to everyone to drink, even to candalalas, everyone is offered renunciation" (T. 201 [IV] 311c14-15: 猶如清淨水一切悉得飲 / 乃至斿陀羅各皆得出家), and the Buddha ultimately saves him. For the same image of water, see below for the story of Nitha. The implication here that ordination is offered to candālas is taken up below.

Mukhopadhyaya 1963: 73.1-6 (Cowell and Neil 1886: 383.10-17):

jātim bhavān paśyati śākyabhikṣuṣv antargatāìns teșu guṇān na ceti |

ato bhavā̃̃ jātimadāvalepād àtmānam anyāmís ca hinasti mohāt \|

āvāhakāle 'tha vivāhakāle jāteh parīkṣā na tu dharmakāle |

dharmakriyāyā hi guṇā nimittā guṇāś ca jātim na vicārayanti $\|$

yady uccakulīnagatā doșā garhām prayānti loke 'smin |

katham iva nīcajanagatā guṇā na satkāram arhanti \| 
qualities; good qualities do not pay attention to caste. If those belonging to high-status families, having faults, are censured by everyone, how is it that those belonging to a low status, having good qualities, do not merit reverence?

As one final example, we may return to Pāli sources and quote a few verses found in the Anguttaranikāya:11

So too, among human beings it is in any kind of birthamong khattiyas, brahmins, vessas, suddas, caṇūālas, or scavengersamong people of any sort that the tamed person of good manners is born:

one firm in Dhamma, virtuous in conduct, truthful in speech, endowed with moral shame;

one who has abandoned birth and death, consummate in the spiritual life,

with the burden dropped, detached, who has done his task, free of taints;

who has gone beyond all things [of the world] and by non-clinging has reached nibbāna:

an offering is truly vast when planted in that spotless field.

Alongside these assertions of equality, however, it is equally plain that Buddhist sources are emphatic in holding that ksatriyas, the so-called warrior class and the class into which the Buddha is held to have been born, ${ }^{12}$ are superior to the brāhmanas, the so-called priests. Brahmanical sources, of course, begin-

11 AN i.162,16-23, trans. Bodhi 2012: 256 (the same at AN iii.214,6-13, trans. Bodhi 2012: 794795):

evam eva manussesu yasmim kasmiñcijātiyam |

khattiye brāhmaṇe vesse sudde caṇ̂ălapukkuse \|

yāsu kāsuci etāsu danto jāyati subbato |

dhammaț̣tho sīlasampanno saccavādì hirīmano \|

pahinajātimarano brahmacariyassa kevalī|

pannabhāro visaṁyutto katakicco anāsavo \|

pāragū sabbadhammānaṁ anupādāya nibbuto |

tasmim yeva viraje khette vipulā hoti dakkhinā $\|$

12 References to the Buddha having belonged to the kșatriya class are found in DN 1.115,3132, 133,9-10, and MN ii.167,9-10. The Mahāvadānasūtra (parallel to the Pāli Mahāpadāna, DN ii.2,29-3,11) offers the following (Fukita 2003: 38.18-21): Vipaśyī samyaksambuddhah kṣatriyo jātyābhūt Śikhī samyaksambuddhah kșatriyo jātyābhūd Viśvabhuk ca | Krakasundah samyaksaṁbuddho brāhmaṇo jātyābhüt Kanakamunị̣ Kāśyapaś ca | asmākam apy etarhi kșatriyā jātir bhavati iyam atra dharmatā. Here three former buddhas were 
ning with the Rgveda, maintain that the brāhmanas are the highest caste, and kșatriyas the second. ${ }^{13}$ Buddhist sources, clearly aware of this claim, maintain on the contrary that while this may sometimes be true, in our age, the inverse is rather the case. The Majjhimanikāya says: "The khattiya is the best among those who rely on lineage; the one endowed with knowledge and [good] conduct is the best among gods and men,"14 and the Dighanikāya maintains that "Even when a khattiya has fallen into utmost degradation, still then just the khattiyas are superior and brāhmanas inferior."15 This idea is found also for instance in the Lalitavistara, in a context to which we will return below: ${ }^{16}$

Why, monks, did the bodhisattva examine [his future] family? Bodhisattvas are not born into inferior ( hìna) families, neither into cand àla families, nor bamboo-worker ${ }^{17}$ families, cartwright families, nor pukkasa ${ }^{18}$

kșatriyas, three brahmins, and the Buddha speaks of himself as a kṣatriya. Levman 2013: 159 is wrong, therefore, when he claims that "the Buddha never calls himself a khattiya."

13 It may be apposite to mention that naturally Brahmanical (aka Hindu) attitudes toward caste are also not entirely uniform. For some of the complexities of the notions involved with tantric Śaivism, see Sanderson 2oogb.

14 MN i.358,28-29: khattiyo sețtho jane tasmim ye gottapațisārino | vijjācaranasampanno so sețtho devamānuse. The verse is common, for instance DN i.99,8-9; iii.98,4-5; 99,1-2, and a number of other instances. It was noticed already by Chalmers 1894: 344 .

15 DN i.99,3-5: yadā pi khattiyo paramanihinatam patto hoti tadā pi khattiyā va setțhā hìnā brāhmanāa. This occurs just before the verse just cited.

16 Hokazono 1994: 306.13-19 (Lefmann 1902-1908: 20.1-8): kim kāraṇam bhikșavo bodhisattvaḥ kulavilokitam vilokayati sma | na bodhisattvā hinakuleșūpapadyante caṇdālakuleșu vā veṇukārakule vā rathakārakule vā pukkasakule vā $\mid$ atha tarhi kuladvaya evopapadyante brāhmaṇakule kṣatriyakule ca | tatra yadā brāhmaṇaguruko loko bhavati tadā brāhmaṇakule upapadyante | yadā kșatriyaguruko loko bhavati tadā kșatriyakule upapadyante | etarhi bhikșavah kșatriyaguruko lokah tasmād bodhisattvāh kșatriyakule upapadyante.

17 Some sources suggest that venukkāra refers to a worker in reeds or basketry, but for instance Mahāryutpatti 3798 smyug ma mkkhan suggests that the understanding as a worker in bamboo is more likely to have been what was understood (and notice in $\mathrm{nn} .67$, 86 below the Chinese rendering 竹作). For a detailed discussion see Jha 1978.

18 Functionally, pukkasa is roughly equivalent to caṇda ạla. It is the Pāli and Buddhist Sanskrit equivalent of Sanskrit pulkasa/paulkasa, which appears along with caṇ̣̂āla (and nișāda, Pāli $n e s \bar{d} d a$ ) already in the Vedic literature referring to non-Āryan tribal peoples (ParasherSen 2006: 420, "The really despicable people in the early Vedic texts were the Canḍāla and Paulkasa who, as objects of spite and abhorrence, were considered the lowest ritually and socially"). For etymological complications related to pulkasa see Kuijper 1991: 54-57. For the niṣāda, see Jha 1974a. In the Amarakośa (Śūdravarga II.10.19-2oab) we find a listing of the terms considered to belong to the same category as candāla: dakșe tu caturapeśalapațavah sūtthāna uṣnaś ca | caṇdāla-plava-mātañga-divākīrti-janañgamāḥ || nipādaśvapacāv antevāsi-cāṇ̂āla-pukkasāḥ. For a few observations based on Pāli sources see Horner 1938-1966: II. 173-174, in the notes. I am not sure that Matsunami 1992 adds much. 
families. Instead, they are born into only two families: brāhmaṇa families and kṣatriya families. In that regard, when the brāhmanas hold sway in the world, then they are born into a brāhmana family, and when the kșatriyas hold sway in the world, then they are born into a kșatriya family. Therefore, monks, since the kșatriyas hold sway in the world [now], bodhisattvas are born into a kṣatriya family.

We should not overlook the specific concern of Buddhist authors with the Buddha's caste lineage. This is clear in the story of his ancestral line, found throughout Buddhist texts belonging to various traditions, according to which the sons of king Okkāka (Sanskrit Ikṣvāku) were banished, and sent into exile along with their sisters. ${ }^{19}$ The version in the Ambatțhasutta of the Dighanikaya says that "out of fear of the mixing of castes (jātisambhedabhaya), they cohabited together with their own sisters." ${ }^{20}$ It is the offspring of these incestuous sibling unions who become the Buddha's forebears. This refers to a concern about the offspring of "mixed marriages" (see below n. 29), and in this case the concern that by failing to locate women of appropriate caste, the princes would produce inferior children. This concern with caste purity is paralleled in the clichéd stock phrase that begins many Indian Buddhist narrative (avadāna) tales, in the notice of an initial marriage carried out between two families, namely that a man "took a wife from a suitable family" (sadrśāt kulāt kalatram ānìtam), signifying that the family of the bride had an appropriate caste relation to that of the groom. ${ }^{21}$ Although we might think here of the message we encountered above in the Kuñă $\bar{a} v a d \bar{a} n a$ that in marriage one rightly considers caste, it is striking that the insistence on caste lineage in the Ambatthasutta refers specifically to the Buddha's antecedents. For the family ancestors of the Buddha, this concern for caste suitability is so overwhelming that it seems to trump even the otherwise dominant, if not virtually ubiquitous, taboo against close-kin marriage. Clearly, for those who composed the story of the Buddha's life, caste status was very important indeed.

Perhaps in some contrast to this, arguments about the meaninglessness of caste are also, finally, found theorized in very careful ways in the works of

\footnotetext{
19 For a detailed discussion, see Silk 2008.

20 DN i.92,21-22 (III.1.16).

21 This expression is common in the Divyāvadāna (see Hiraoka 2002: 157) and elsewhere. For the Pāli Jātaka, see Fick 1920: 52. In Kathāsaritsāgara vı.33.26c, a suitable wife, "equal to himself," is indicated with the term àtmānurūpā bhäryā. The term ātmānurūpā is also found in Kumārasambhava I.18d, commented by Mallinātha ātmānurūpāì kulaślasaundaryādibhih sadrśím. There is no explicit reference here to jāti or varṇa, but the reference to kula seems to imply this.
} 
scholars belonging to the epistemological (pramāna) tradition, particularly Prajñākaragupta. This material has been discussed in a masterly fashion by Eltschinger, who explores what he terms the "naturalization of caste," through which the Buddhist thinkers argue against their brahmanical opponents that caste is not something which belongs to the nature of the world but is rather an imposition on the world, a human fiction. ${ }^{22}$ Eltschinger (2012: 170-171) concludes that, from a philosophical perspective, "All the Buddhist arguments indeed converge in affirming that caste is not an ontological determination of the human being. It does not condition, nor does it affect, his mode of being or psychophysical constitution."

All of this concerning the status of the four castes may be taken as well established and relatively uncontroversial, leaving aside nuances and questions as to whether and how this rhetoric of equality was actualized in daily life. Concerning this last point, however, there is some evidence that Buddhists were perceived to actually act in accord with this rhetoric, or at least they are (at least once) presented that way for what may well be no more than polemical reasons. The Kaśmīri scholar Bhațta Jayanta (last quarter of the gth c.) authored a play, the Agamadambara, in which we find the claim that the Buddhists treat all castes equally, and moreover even in that most sensitive of settings, the meal. Sanderson writes: "Note the distaste expressed by the brahmin Samkarșana in the Agamadambara ... when, in a Kashmirian monastery, he notices that Buddhist monks do not form separate lines according to caste when they eat together: 'Persons of all the four caste-classes (varna) and even from the mixed castes (varnasamkara) are eating together in a single line."' 23 While this might indicate an observed practice, the satirical nature of the passage is emphasized by the fact that immediately following it, it is said that the monks are served food by "buxom slave girls," ${ }^{24}$ which at least prima facie does not seem very

22 See Eltschinger 2012, and now also 2017. This formulation is not intended of course to deny the Buddhist (nearly?) universal committment to karma as one of the key operative principles. And this applies in the present case as much as anywhere. While the doctrinal nuances are complex (but ably dissected by Eltschinger), there is more than ample evidence that Indian Buddhist texts explicitly attribute "inequalities," if not caste as such, to one's past karmic acts. In a 4-fold category in the Karmavibhanga (Lévi 1932: 68.15-17; Kudo 2004: 138.13-15, 139.13-15, 270-273), someone who is merely not generous, but does not perform any evil act (sa dānaṁ na dadāti | na ca tena kimìit pāpakam karma krtà் bhavati), ends up born into a poor family, without sufficient food (sa yadā manușyeșūpapadyate daridreșu kuleșūpapadyate | alpānnapānabhojaneșu).

23 Sanderson 2009a: 29on693, quoting the line: catvāro varnā varnasamkarā api vā sarva evaikasyām pan்ktau bhuñjate; see Dezső 2005: 1.81 for the line in context.

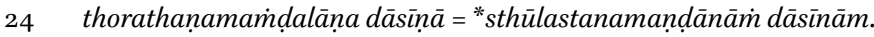


plausible. This passage, then, may perhaps indicate something about the actual social situation of Buddhist monasteries in Kaśmīr, but it might equally well suggest how one not well-disposed opponent wanted to portray them. Yet, at the same time, even if the depiction is not factually accurate, it must demonstrate that the author Jayanta felt that his audience in Kaśmīr would find it plausible that the Buddhists avoid caste distinctions, even in eating. We should, finally, not forget that even if the observations are factually correct for their author's Kaśmīri situation, it need not follow that the same situation prevailed elsewhere in South Asia at any particular time.

Outcastes

Granting the overwhelmingly consistent Buddhist rhetoric about caste equality (or at least non-discrimination), and even its possible instantiation in institutional settings, ${ }^{25}$ it is plain that what applies to the four castes need not necessarily extend to those considered beyond and, without a shred of doubt below, this classification, namely those belonging to the category, or categories, we all too vaguely refer to as "outcaste," among whom the very lowest of the low are the candālas, the outcastes par excellence. ${ }^{26}$ That is to say, it may be that those within the four recognized castes—brāhmaṇas, kṣatriyas, vaiśyas, and śudras - are thought of in one way, and those outside this four-fold division in another. ${ }^{27}$

25 Perhaps a propos of this, I have not run across mentions of caste in discussions of the "uninterrupted begging round" (Skt. sāvadāna, Pāli sapadāna), in which monks go from house to house begging, not skipping any house, rich or poor. See Lamotte 1976: 5on19. At best however this is negative evidence, and thus hard to assess.

26 The canda a la is not the only type of outcaste, but he is the paradigm, and therefore rhetorically speaking it is the candūala who is referred to. It would take a more comprehensive study than the present one to evaluate whether any of the other categories found systematized in the so-called Hindu Law Books are actually taken into account in extant Indian Buddhist literature in anything other than a tangential manner (that is, for instance, as anything other than as items in standard lists). On the category one may read with profit for instance Jha 1975, 1986.

27 It is perhaps needless to say that we must exercise care in our reading of possible evidence, and not imagine references where none exist. For instance, despite considerable disagreement among modern scholars, the appearance in AN v.210,9 of the word vevanniya has nothing to do with caste. It parallels the Sanskrit vaivarnika, and refers to physical appearance, unrelated to varna in the sense of caste or class. Likewise, in Goodman's translation of the Śikșāsamuccaya (2016: 114, and 38onlvii), in a quotation from the Ratnameghasūtra, he imagines a reference to untouchables in the text's cand $\bar{d} \bar{a} v \bar{a}$ kukkurās, citing Tib. khyi za ba, but in fact both the Sanskrit and Tibetan mean "vicious dog." (Unfortunately, 
Much has been written about the candālas, who they were, where they came from, and what their status was. ${ }^{28}$ It seems clear that the concept originated with marginal tribals, that is, those who lived in "uncivilized" zones, whose habits and practices were perceived to be barbarian (a term with a similar background), and thus despicable. ${ }^{29}$ Indeed, this association of outsiders

according to the kind information of Vinītā Tseng, now editing the Ratnameghasūtra, the manuscript folio on which this passage would occur is lost.) It occurs in precisely this equivalence and meaning for instance in the Yogācārabhümi, in the Śrāvakabhūmi, and perhaps elsewhere. Moreover — and this is important — the categories of canda a la and untouchable are not, strictly speaking, the same, and thus the former term should not be translated by the latter. See n. 97 , below.

28 Thieme 1994:326 suggests that the very word, signifying "the name of a member of a rather despised caste, may go back to an adjective *canda + ala- 'of horrible food." Note that the word is also sometimes spelt cāndâala. (Miyasaka 1995a: 32n1, conveniently lists Chinese transcriptions and translations of cand $\bar{a} l a$, though the latter may need some closer attention as identifying exact equivalents for closely related terms can be difficult.) The Kalpadrumāvadānamālā (date unknown, but perhaps a Nepalese composition, and thus to be used with caution as evidence for Classical Indian Buddhism), taking advantage of the apparent etymology, states "We call candūa las those men who, bloodthirsty and showing no pity, harm beings and behave cruelly." Ed. Speyer 19o6-1909: II.lviii, vs. 186: tato ye mānavāh krūrā nirdayāh sattvahimsakāḥ | caṇdavrttipracārāś ca canḍālā iti te smrrtāh, trans. Eltschinger 2012: 14 .

Concerning what might in some sense be thought of as a related category, the mleccha, my impression is that it is an exaggeration to write, as Parasher 1979: 111 does, that "In early Buddhist and Jaina writings, the milakkhas were simply known for their unintelligence, ignorance and a way of life that was unconducive to the attainment of nibbana." My impression rather is that the category is almost entirely absent, at least in Buddhist literature, and when mentioned passed over in only a few words.

29 Over time, the concept of the canda a la was theorized in Indian treatises, and ultimately, as expressed most clearly in the Dharma tradition, came the rationalization that canda alas come from "mixed marriages," specifically a form of pratiloma (inverse) relationship, in which the woman's family has a higher status than the man (the opposite form of marriage, the anuloma, confers the father's status on the child). According to some, then, a caṇ̂a ạla results from the union of a śüdra man with a brāhmaṇa woman (but as Jha 1986: 5 clarifies, "The Caṇ̂āas as a veritable social group were in any case never the actual mixed progeny of śūdra males and brāhmaṇa women"). See the convenient schemes in ParasherSen 2006: 447-451. Note that some texts go even farther, however, with the result (which probably is in this respect, even more than the system itself, a theoretical artifact) that as an extreme case, procreation between a caṇ̂̄ala man and a brāhmaña woman produces a child whose status is even lower than that of a caṇ̣̂ăla; Yamazaki 2005: 197. I do not know of this status appearing in non-Dharmaśāstric literature.

That the concept of the candāla represents an extreme is shown already by passages in which it is evoked to demonstrate the inexplicable power of some notion. For instance, the quite early Briadāranyaka Upanișad refers to the "person embraced by the self (ätman) consisting of knowledge [prajña] ]" (4.3.21), and goes on, "Here a father is not a father, a 
with low practices is an understandable idea, and one that continues to have potency in a somewhat more metaphorical sense even down to today (one might think here of the English word "outlandish," or the polyvalency of the French "étranger").

\section{$4 \quad$ Status and Spiritual Potential of Outcastes}

In one of our very earliest Buddhist sources, the Suttanipāta $(136,142)$, we find the assertion: "Not by birth does one become an outcaste (vasala), ${ }^{30}$ not by birth does one become a brāhmaṇa. By one's action one becomes an outcaste,

mother is not a mother, worlds are not worlds, gods are not gods, and Vedas are not Vedas. Here a thief is not a thief, an abortionist is not an abortionist, an outcaste is not an outcaste, a pariah is not a pariah, a recluse is not a recluse, and an ascetic is not an ascetic. Neither the good nor the bad follows him, for he has now passed beyond all sorrows of the heart." atra pitāpitā bhavati mātāmātà lokā alokā devā adevā vedā avedāh |atra steno 'steno bhavati bhrūnahābhrūnahā cāṇ̣̂ālo 'caṇ̣̂ālah paulkaso 'paulkasaḥ śramaṇo 'śramañas tāpaso 'tāpasah | ananvāgatam punyenānanvāgataì pāpena | tīrno hi tadā sarvāñ chokān hrdayasya bhavati. Text and trans. in Olivelle 1998: 114-115.

$30 \quad$ vasala $=$ Skt. vrșala ; in Chinese (T. 99 [102]) represented by the apparently otherwise unattested lingqunte 領群特, (OMC after Schuessler 200g: rẹ? gwən dâk; if it is a transcription, I cannot suggest an origin) which remains obscure to me (as it did to Miyasaka 1992: 102n15). See also Choong 20o9: 375-376, Miyasaka 1992: 82-84. The term vasala does not frequently reappear in Buddhist literature; here as in much else, the Suttanipāta stands apart from later Buddhist literature.

I owe the following to the kindness of Rafal Felbur: The Chinese monk-scholar Yinshun 1954: 55 claims that lingqunte 領群特 is a translation of vasalaka. He speculates that the translator(s) may have arrived at it by reading vasa as "cow" (牛牛). Hence, vasalaka being originally a slightly derogative term for "someone from Vesālī," [I have no idea where this idea comes from-JAs] became "cow that leads the masses." In opting for this term the translator(s) may have been trying to convey the honorific idea of the Buddha being like a "strong cow that leads the people" with his teachings. There are serious problems with this, including the fact that there is nothing at all in the sūtra in question that suggests such an honorific depiction of the Buddha (the interlocutor brāhmana never shows any respect for the Buddha throughout, until the final moment of conversion, and whenever he addresses the Buddha directly, before the very end of the text, he does so with a sense of disdain). Second, in the verse section, in which the Buddha delivers a teaching on the "dharma of the vasalaka" 領群特法, the lingqunte is presented as having only negative qualities-all a result of his negative karma. Finally, Yinshun correctly observes that in the parallel passage in the Bieyi za ahan jing 別譯雜阿含經 (T. 100 [268] [II] 467b27) the same underlying term is given in transcription as zhantuoluo 旃陀羅, candāala. The same transcription occurs also in the T. 99 text, in the verse section, 29a19: 生旃陀羅家.

I (JAS) think we must conclude that Yinshun's speculations do not lead us anywhere and lingqunte 領群特 remains a mystery. 
by one's action one becomes a brāhmana.."31 The context of this is the chapter of the Suttanipāta called Vasalasutta. Here a brahmin attacks the Buddha calling him vasalaka, outcaste (the suffix $-k a$ adds a further element of contempt). ${ }^{32}$ Just as he has famously redefined the term brähmaṇa, removing it from the brahmanical hierarchy system and making it a spiritual denomination, here the Buddha redefines vasala, asking "Do you know, brāhmaṇa, what an outcaste is, or the things that make one an outcaste?"33 When the brāhmaṇa confesses that he does not, the Buddha explains, in essence saying that an outcaste is one who is angry and so on, commits violence, steals, lies, engages in sexual misconduct, is unfilial, gives bad advice, conceals his misdeeds, is inhospitable, is arrogant, criticizes the Buddha or his community, or falsely claims to be an arhat. This catalogue of negative actions (not incidentally closely convergent with basic Buddhist vows and prohibitions) thus entirely redefines the status of outcaste from one that is birth-based to one that is deed-based. The composer of the verses (who may or may not be the same as the composer of the prose introduction), even in denying hierarchy, however, plainly acknowledges its existence, taking what are obviously the diametrically opposed poles of his scale - the highest, the brāhmana, and the lowest, the outcaste — to deny the inherent validity of these assignments. We should notice precisely what the key verse actually says: "Not by birth does one become an outcaste, not by birth does one become a brāhmaṇa." There is in fact no denial here of the validity of these extreme, polar categories - only a denial of the fact that one is positioned in either status merely by birth. Here we must not forget the basic doctrinal lynch-pin of Buddhist thought, namely that everything about one's status is a result of nothing other than one's karma, that is, one's actions. ${ }^{34}$ In this light, the Suttanipāta's claim appears not at all revolutionary or egalitarian as a social philosophy. Rather, in the process of asserting the centrality of actions, it actually affirms the strict social hierarchy it might, at first blush, seem to deny.

There are, however, a number of examples in Buddhist literature of depictions which do actually seem to deny, at least implicitly, the inherently low

31 na jaccā vasalo hoti na jaccā hoti brāhmaṇo | kammanā vasalo hoti kammanā hoti brāhmano. Trans. Norman 1992: 16, slightly modified. That this does not come from the very oldest portion of the Suttanipāta does not seem to me crucial in the present context.

32 See Jamison 2009.

33 jānāsi pana tvam, brāhmaṇa, vasalaì vā vasalakaraṇe vā dhamme. Cp. Norman 1992: 14.

34 Eltschinger 2012 discusses the differences in doctrinal positions a propos this point between, chiefly, the Vaibhāṣikas and Vasubandhu; for more, see Eltschinger's very detailed discussion. 
status of the candāla. ${ }^{35}$ In the first place, and commonly cited in scholarly literature, it should be noticed that several Pāli Jātakas depict the bodhisattathe Buddha-to-be in a former life-as a canda $\bar{a} l a{ }^{36}$ and such passages have been understood, at least by some modern scholars, to deny the idea that even status as an outcaste has some definitive impact on one's spiritual potential. However, it is essential to recognize that this refers not to the status of the bodhisatta in his final life, but in one of his (technically speaking, infinite) former lives. There are other examples of the same formulation. ${ }^{37}$ Since all

35 In the survey presented here, I do not offer any hypothesis about possible chronological, geographical or sectarian patterns of attitudes expressed toward caṇ̂ălas. However, it must be remarked that Shimoda 1991 put forward the suggestion that there was a shift over time in the attitude toward caṇ̣̂alas of the dharmabhānakas who preached the Mahāyāna Mahāparinirvāna-mahāsūtra, the earlier period being one of acceptance which later gave way to intolerance. If this hypothesis were correct it would necessitate a close reexamination of all our other materials concerning this question, since it would imply that we can offer suppositions concerning chronology, or at least relative chronologies, on this basis. However, I cannot agree with Shimoda's hypothesis which is, I believe, based on a rather strong over-reading of his materials. As far as I can tell, he based his argument concerning the early tolerance of candālas on one passage in one of the Chinese translations of the Mahāyāna Mahāparinirvāna-mahāsūtra, in which it is stated that in times of internal disorder in a land the dharma-preacher may take recourse to the protection offered by candālas and those carrying weapons, and may travel in dangerous areas in their company. Other-according to Shimoda later-versions of the same text contradict this "liberal view." I will not enter into a detailed critique of Shimoda's theory here, but it may suffice for the present to note that there are numerous exceptional rules in various Buddhist texts allowing otherwise impermissible activities in times of strife and hardship (âpaddharma), and I cannot see that the passage so emphasized by Shimoda should be treated any differently. On the general principle in Buddhist contexts, see Schopen 2018.

36 For instance, in Jätaka 3o9, "Chavaka," the bodhisatta was a chavaka=śvapaka (see Alsdorf 1974), literally a dog-cooker (but also see Norman 1958: 47 with n7, who discusses Sopāka < śvapāka, or perhaps *śavapāka?), or Cittasambhūta (Jātaka 498). See Law 1937: 25 for further examples. Problems in interpreting the relevance of these stories aside, the utility of the Jätaka prose as sources of Indian Buddhism seem to me potentially problematic, since they belong to a Sri Lankan milieu, and in the absence of parallels I refrain from citing Pāli Jātaka prose evidence here.

37 The Bhadrakalpika-sūtra offers a list of (according to the count of Skilling and Saerji 20142018, upon whose work the following is based) 994 buddhas, for almost all of whom there is an identification of the social position or occupation of the individual when he or she first made the aspiration to awakening. Again, this does not, however, refer to the last life, and there is therefore no contradiction with the stipulation discussed above that buddhas (i.e., bodhisattvas in their last life) are born as either kșatriyas or brāhmanas. Speaking of the initial moment of aspiration, there is a wide range of social statuses given, ranging from gods, kings and court priests down to the lowest social strata, including not only one mention of candāla $(\# 350)$, but also other occupations which form part of the standard lists of those of low status: cartwright (rathakāra; \#16, and 16 others), leather-worker (car- 
beings cycle through samsāra, being born as high and low (and as animals and gods and hell-beings), from a doctrinal point of view, one's erstwhile identity is irrelevant for one's present spiritual potential. Such references to former lives of the Buddha, therefore, do not demonstrate anything. So much is clear. Be that as it may, this is not the only type of evidence available, and there does exist evidence of attitudes toward candạlas which do seem nondiscriminatory.

While, as we saw above, there are a number of examples of claims made for the high status of the family of the Buddha-the Pāli term is usually ucca, in contrast to nica, low-in the Majjhimanikāya the Buddha is made to proclaim: ${ }^{38}$ "I do not say that one is better because one is from an high status family (uccākula), nor do I say that one is worse because one is from an high status family." The reason, as the sequel explains, is that one from a high-status family, or wealthy, may nevertheless commit evil deeds. ${ }^{39}$ This approach seems to

makāra, \#20, and 4 others), śūdra (\#433), bamboo-worker (venukāra, \#926), and umpteen others of clearly low status. Perhaps needless to say, almost all the figures given in this list are otherwise entirely unknown and therefore have no hagiographical traditions associated with them.

Note that the Mahāyāna Mahāparinirvāna-mahāsūtra (Habata 2013: 357, §526; T. 374 [XII] 423b7-9 = T. 375 [XII] 664b24-26 = T. 376 [XII] 895b24-26) also speaks of a candāa la who will quickly become a buddha, but this once again refers to his status when he first makes the aspiration to awakening, not his status at birth in the life in which he finally attains buddhahood, and it is explicitly spoken of as a prophecy or prediction. Matsunaga 1991: 287 misrepresents this key fact.

38 MN ii.179,13-15: nāhaṁ brāhmaṇa uccākulīnatā seyyam so ti vadāmi | na panāham brāhmana uccākulīnatā pāpiyam so ti vadāmi. This is stated in the context of a passage in the immediately preceding sutta: MN ii.167,9-11: samano khalu bho gotamo uccākulā pabbajito ādīnakhattiyakulā | samaṇo khalu bho gotamo aḍ̣̂akūlā pabbajito mahaddha$n \bar{a}$ mahābhogā, "Sirs, the recluse Gotama went forth from an aristocratic family, from one of the original noble families (khattiyakula). Sirs, the recluse Gotama went forth from a rich family, from a family of great wealth and possessions." Trans. Ñānamoli 1995: 777.

39 See in this regard also SN i.168,9-12 (VII.I.9.9): mā jätim puccha caraṇañ ca puccha kaț̣̂ā have jāyati jātavedo | nīcākulīno pi muni dhitimā ājānīyo hoti hirīnisedho. Trans. Bodhi 2000: 262: "Ask not of birth but ask of conduct: Fire is indeed produced from any wood. A resolute sage, though from low family, Is a thoroughbred restrained by a sense of shame." Bodhi 2000: $447 \mathrm{n} 448$ translates the commentary: "It is not the case that only fire produced from a pure type of wood, such as sal-tree logs, can perform the work of fire, but not fire produced from the wood of a dog's trough, etc. Rather, by reason of its flame, etc., fire produced from any kind of wood can do the work of fire. So you should not think that only one born of a brahmin family is worthy of offerings, but not one born in a caṇāāla family, etc. Whether from a low family or a high family, an arahant sage is a thoroughbred—resolute, restrained by a sense of shame." 
conform to some narrative portrayals found in various texts. An example is the trope which lauds the humility of the candāla. In the Ariguttaranikāya, we find the following: ${ }^{40}$

As an example, a young candāla boy or girl, with a container in hand and clad in rags, entering a town or village, enters having produced a humble/low mental attitude. In just this way, Venerable Sir, I live with a mentality the same as that of a young candāla boy or girl, expansive, lofty, measureless, free from hatred, harmless.

This is closely paralleled in the Madhyamāgama: ${ }^{41}$

World-honored One, take as an example a canḍala boy who, having had both hands cut off, with his mind supremely low, wanders going from village to village, from town to town, and wherever he goes he commits no offence. World-honored One, I too am like this: my mind is like that candāala boy with hands cut off. Without bonds, without hatred, without wrath, without quarrels, extremely vast, incredibly lofty, [characterized by its propensity for] immeasurable good practices, it wanders pervading the entire world.

Similarly, in the Ekottarikāgama we read that "Again, it is like a female canḍāla, who clutches her tattered clothing and while begging for food among people yet feels no prohibitions. I too am like this. World-honored One, I too wander far and wide with no notion of entering into conflict with others." ${ }^{2}$ A similar mention of the candāla as the epitome of humility is found in the Adhyāsayasamcodana, which states, amidst a list of qualities of the bodhisattva, "If we do not dwell with humble minds, with minds like those of candāalas, we would have

40 AN iv.376,11-16: seyyathāpi bhante caṇḍālakumārako vā caṇd̄ālakumārikā vā kalopihattho

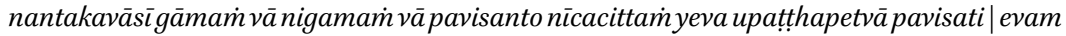
evaṁ kho aham bhante caṇ̂̄ālakumārakacaṇ̂̄ālakumārikāsamena cetasā viharāmi vipulena mahaggatena appamānena averena avyāpajjena. The precise meaning of kalopi is not sure, but also not germane to the subject at hand.

41 MA 24, T. 26 (I) 453a11-15: 世尊, 猶旃陀羅子, 而截兩手, 其意至下, 從村至村從邑至 邑, 所遊行處, 無所侵犯。世尊, 我亦如是。心如截手斿陀羅子。無結、無怨、 無急、無猙, 極廣、甚大、無量善修, 遍滿一切世間成就遊.

42 T. 125 (II) 713a24-26: 亦如旃陀羅女著弊壞衣, 在人間乞食, 亦無禁忌。我亦如 是。世尊, 亦無想念當興猙訟, 而遠遊也. The term jinji 禁忌 may include some notion of taboo, including over food. 
lied to the Tathāgata." ${ }^{43}$ The Mahāyāna scripture Ratnameghasūtra contains several passages along the same lines. Bodhisattvas, this sūtra maintains, are noble (ajjāneya) because they possess ten qualities, one of which is that they "live in the world with a most base mind, like young candālas. And they become free of pride, arrogance and conceit, because they constantly have in mind the idea of alms." ${ }^{\prime 4}$ Again, the pride (māna) of a bodhisattva with ten qualities is

43 Quoted in the Śikșāsamuccaya (Bendall 1897-1902: 98.16-17; ms Cambridge Add. 1478 54b1-2): saced vayam bhagavan nīcacittāś caṇ̣̂ālasadrśacittā na viharema visamvādito asmäbhis tathāgato bhavet. All other versions (the Tibetan of the sūtra and 2 Chinese translations, and the Tibetan and Chinese of the Sikșāsamuccaya) add "and dogs" to caṇ̣̂ālas; we might emend to "nícacittāśś śvacandala $\bar{a}^{\circ}$. It is easy to see how śva could have dropped out graphically.

44 Quoted in the Śikșāsamuccaya (Ms Cambridge Add. 1478 74a6-7; cf. Bendall 1897-19o2: 150.12-13): caṇ̂āalakumāropamāś ca loke viharanti nīcanīcena manasā | mānamadadarpyavigatāś ca bhavanti paindilyasamjiñāyāh satatasamitam pratyupasthitatvād iti. The last clause is not particularly easy to understand, and my translation is somewhat speculative. D 3940, dbu ma, khi 85a1-2: gzhan yang dman pa'i yid kyis gdol bu lta bur'jig rten na spyod pa yin | rtag tu rgyun mi 'chad par bsod snyoms slong ba'i 'du shes nye bar gzhag pas dman zhing dman pa'i yid kyis nga rgyal dang rgyags pa dang dregs pa dang bral ba rnams yin no zhes gsungs so. Thanks to the generosity of Vinitā Tseng, I can refer to the Sanskrit manuscript of the Ratnamegha she is now editing, which reads in her transcription as follows (36b7-37a1): caṇ̣̂ālakumārakopamāś ca bhavanti | anuvicaranti nīcanīcena cittena | mānamadadarppadrșțivigatāś ca bhavanti paindililyasamjñāyāḥ satatasamitam pratyupasthitatvāt. I do not enter here into the details of the establishment of the text and the relation between the manuscript and its citation in the Śiksaasamuccaya, which will be addressed by Tseng in her edition. Kanjur version D 231, mdo sde, wa 58a5-6: dma' ba dma' ba'i yid kyis gdol bu ltar 'jig rten na spyod pa rnams yin | rtag tu rgyun mi chad par bsod snyoms blang bar'du shes nye bar gzhag pas nga rgyal dang $\mid$ rgyags pa dang $\mid$ dregs pa dang bral ba rnamsyin. Cp. the trans. Dharmachakra Translation Committee 2019:1.321. Chinese versions split what seems in Sanskrit and Tibetan to be one item into two (5 \& 6): T. 659 (XVI) 257a10-12: 行於世間如斿陀羅卑下之子, 以下卑心, 遠離自高傲慢狂醉 故...恒乞食活次第平等故; T. 489 (XIV) 726c15-17: 能於世間自卑其身, 如旃陀羅謙 下其意...遠離憍慢, 常於他人起智者想; T. 66o (XVI) 305c6-9: 随順諸法平等, 理趣 通達, 實相遊止, 世間心常下劣, 如斿茶羅...於一切時常能起於乞匈之想, 遠離我 慢憍醉放逸.

Perhaps conceptually related to this is a passage in a text we will encounter again below, the Ratnarāśi, which advises the alms-begging monk (piṇdacārika) regarding the attitude to take while begging as follows: "In absolutely no way should he have any ideas about taste with regard to good foods. He should train himself, thinking thus: In this way I should be like a young caṇ̂ăla and purify my body and mind, but I should not purify my body with food. Why? No matter how good the food that is eaten, it all ultimately flows out as pus. Ultimately it is disagreeable. Ultimately it is evil-smelling. Therefore, I should not desire good food." Silk 1994: §vi.2: des kha zas bzang po rnams la ro bro ba'i 'du shes thams cad kyi thams cad du bskyed par mi bya'o || des 'di ltar bdag gis gdol pa lta bu dang | lus dang sems gtsang mar bya'i kha zas kyis lus gtsang mar ni mi bya'o \| de cii phyir zhe na 
destroyed, one of which is "I go for alms with a most base mind, like a young candāla." 45 Now, it may be granted that such references are ambiguous: they seem to be referring to cand $\bar{a}$ las in some positive way, but gain their power from the expectation that candalas are humble for a good reason, that they deserve to be humble (we might recall the witticism that "He is a humble man with much to be humble about!"). Therefore, one could certainly justifiably argue that such usages actually do not present any positive view of the canda a la.

However, various texts do contain passages in which the spiritual potential of candālas themselves appears to be explicitly accepted. The *Vidyutprāptasūtra speaks of a candāla butcher named Fearsome (可畏) ${ }^{46}$ who, despite being in a rage to butcher a cow, hears the preaching of a Tathāgata, and immediately becomes awakened, his blood-lust gone. He tells the Tathāgata he would like to renounce the world, and the Buddha makes him a śramana with the ehi bhikșu ("Come, monk!") formula, thereby conferring the upasampadā ordination precepts upon him. ${ }^{47}$ The Buddha then preaches to him about the bodhisattva practices, and the former butcher, upon hearing this, attains the advanced spiritual fruit of the anutpattikadharmakșānti, the profound understanding that nothing exists inherently, and subsequently the former butcher gains rebirth in the heaven of Maitreya, Tușita. ${ }^{48}$ In contrast, then, to the Jātaka stories

| zas bzang po ji snyed cig zos kyang de thams cad ni tha mar rnag tu zag go | tha mar mi 'thun no || tha mar dringa ba'o \| de lta bas na bdag gis bzang po 'dod par mi bya'o snyam du bslab par bya'o. The corresponding Sanskrit is quoted in the Śikșāsamuccaya (Ms 66a46 = Bendall 1897-1902: 129.16-130.3): tena sarvvena sarvvam rasasamjjña notpādayitavyā | caṇ̂āalakumārasadrśena mayā bhavitaryam cittakāyacaukșeṇa | na bhojanacaukșeṇa | tat kasmād dhetoh | kiyata praṇitam api bhojanam bhuktam sarvvan tatpūtinișyandaparyavasānam durgandhaparyavasānam pratikūlaparyavasānam tasmān mayā na praṇitabhojanākāmkșinā bhavitaryam.

45 Quoted in the Śikṣāsamuccaya (Bendall 1897-1902: 150.18): nìcanìcena cittena canḍ̂̄lakumārasadŕśena piṇ̣̂aya carāmìti nihatamāno bhavati. The version in the sūtra manuscript (quoted after the draft ed. of Dr. Tseng) reads only trivially differently (61a1): nīcanīcena cittena caṇ̣̂ālakumārakasadrśena piṇ̂āya carāmīti nihatamāno bhavati. Kanjur text at D 231, mdo sde, wa 95a2: gdol bu dang 'dra bar dman pa dman pa'i sems kyis bsod snyoms kyi phyir'gro'o zhes nga rgyal bcom payin. Cp. Dharmachakra Translation Committee 2019: 1.537 .

46 Matsunaga 1991: 282 speculates that given the similarity of candāla and canda the latter may have been the name meant here. It is true that the semantic domains of candaviolent, fierce, angry—may overlap with those of wèi 畏—to fear, awe-inducing, but also dreadful — but I am not quite sure about the suggestion.

47 At least this is how I understand the text (T. 310 [20] [XI 485b29-c1): 善來比丘, 即成沙 門, 得具足戒. The wording is a bit peculiar.

48 T. 310 (20) (XI) 485b3-c5, esp. b26-c1. Cp. the trans. in Chang 1983: 16o. Since the Tibetan translation is a rendering of the Chinese, I refer only to the former here. 
referred to above, here the spiritual attainment takes place in the very life in which the individual was born as a candāla. Another example is found in a well-known episode in the Śärdūlakarnāuvadāna. ${ }^{49}$ This text is often cited for its presentation of the nested jātaka story of king Triśanku, the candāala king of the Mātangas, ${ }^{50}$ and the way in which this episode is deployed by the Buddha in his argument to king Prasenajit against caste. The frame story has Ānanda encounter the Mātanga girl Prakrọti (her very name suggests some fundamental naturalness), who falls in love with him. Through the Buddha's intervention, she asks him to ordain her. There follows a small comment which is likely to be a later interpolation, of which only the final words, mentioning ordination, are old, in which the Buddha states that "having entirely purified, by means of a dhäraṇi [called the Dhäraṇī] which Purifies One From [Rebirth in] All of the Unfortunate States, all of the sins which the Mātanga girl Prakrti had acquired in her previous lives[, sins which fated her to] unfortunate rebirths, and liberating her from the Mātanga jāti (caste), he spoke to that Mātanga girl Prakrrti who had become by nature (a pun on prakrti) purified of defilements, saying: 'Come, nun! Practice the celibate life!" "51 Under the Buddha's tutelage she then

49 See Ujike 1984; Isobe 2005; Miyasaka 1993. The textual history of the related works is complex, on which see also briefly Aoyama 1982. See also Karashima and VorobyovaDesyatovskaya 2015: 257-259, with n. 148, a reference I owe to one of the reviewers of this paper.

50 We should recall that in the Suttanipāta 1.7 (Vasalasutta), verse 137, it is stated that Sopāka (see above n. 36 for the possible etymology) is a candūala named Mātanga: caṇ̂alaputto sopāko mātango iti vissuto. For a translation of the commentary, see Bodhi 2017: 555-562. On Mātangas, see the perhaps not so very informative Maetani 1994. I have unfortunately no access to Miyasaka 1976.

51 Mukhopadhyaya 1954: 7.21-8.2: pravrajayatu mām் sugata pravrajayatu mām bhagavān | atha bhagavān yat tasyāh prakrter mātañgadārikāyāh pūrvasañcitāpāyadurgatigamanibhūtaì tat sarvam pāpam sarvadurgatipariśodhanyā dhāranyā niravaśeșena pariśodhya mātañgajāter vimocayitvā śuddhaprakrtinirmalībhūtaì tāìn prakrtim mātañgadārikām idam avocat | ehi tvam bhikṣuñ cara brahmacaryam. Mukhopadhyaya removed from the text the portion after atha bhagavān until idam avocat, which he gives on p. 8n1, explaining p. 219 that "These lines are omitted in translations. Such an idea is against the spirit of Buddhism. Hence we consider it an interpolation." The lines are included in the text in Cowell and Neil 1886: 616.12-15. See also Hiraoka 2007a: II.311ngo. I agree that the lines are an interpolation, but not with the reasoning of Mukhopadhyaya. In fact, the textual history of this material is very complex, and we await a full philological treatment (although excellent work was done by Hiraoka 2007a). See however Hiraoka 1991: 30, 37, who accepts what I consider to be the interpolation and suggests that because the Buddha purified Prakrti with a dhārañi and thus freed her from her caste, "Therefore, the compiler(s) of the Divy[āvadāna] did not consider her to be from the mātanga caste at the time of her ordination." Referring also to several other stories in the same collection, Hiraoka concludes, "These stories reveal that ... at least some (Mūlasarvāstivādin?) groups did not approve of 
attains great spiritual results, but the brāhmaṇa householders of Śrāvastī, hearing that the Buddha has ordained a canda $\bar{l} l a$, are not at all happy. ${ }^{52}$ They wonder whether a cand $\bar{a}$ la girl will be able to correctly carry out the practice of monks, or of nuns, male lay followers or female lay followers. ${ }^{53}$ How, they further wonder, could it be that a caṇ̂āa girl would enter into the houses of brāhmaṇas, kṣatriyas, householders, or great families for alms?

A similar (and perhaps in origin related) story occurs in a number of texts in slightly variant forms. It is known even to the massive compendium called *Mahāprajñāpāramitopadeśa (Da zhidu lun 大智度論), which refers to the story very laconically, stating only that the low status character becomes a great Arhat. ${ }^{54}$ The fullest version is that in the Kalpanāmanditik $\bar{a},{ }^{55}$ a portion

men of humble birth being ordained and joining the samgha. I surmise, therefore, that the Divy. provides evidence of some type of discrimination against those of low social status." I suspect that we have perhaps to do with various stages of editing, and the conflicts between the extant Sanskrit and the other parallel versions provide some evidence of this process.

According to Hirakawa 2000: 170, this is the first instance of a bhikṣunī ordained with this formula. Notice however that, as pointed out by Isobe 2005: 25 , in the version of the story in the early Chinese translation Binaiye 鼻奈耶 (T. 1464 [XXIv] 864c1), the Buddha allows her ordination (世尊許斿茶羅女爲道), but it is actually Mahāprajāpatī who performs that ordination.

It is a pity that A. Rotman, who translated much of the Diryāvadāna, chose not to attempt this section; along with other unfortunate omissions, the result is that we still lack any published full rendering of the compilation in English.

52 Mukhopadhyaya 1954: 10.10-11: aśraușuh śrāvasteyakā brāhmaṇagrhapatayo bhagavatā kila caṇ̂āadadārikā pravrājiteti. Then further 10.11-14: śrutvā ca punar avadhyāyanti | katham̉ hi nāma caṇ̣̂āladārikā bhikșūṇām samyakcaryām carișyati | bhikșuṇinām upāsakānām upāsikānāìn samyakcaryām carisyati | katham hi nāma canḍāladārikā brāhmañakșatriyagrhapatimahāśálakuleșu pravekșyati. The king then repeats these questions.

53 I do not understand the gender inclusivity here, which is perhaps no more than an artifact of the standard phrase, inappropriately copied here.

54 T. 1509 (Xxv) 248a9-10: 如客除翼人名尼陀。佛化度之得大阿羅漢, trans. Lamotte 1944-1980: III.1634, with, as always, valuable notes. See also T. 1509 (XXv) 310a18-20: 如尼 他阿波陀那中: 舍婆提國除粪人, 而佛以手摩頭, 教令出家, 猶不輕之, trans. Lamotte 1944-1980: V.2318-2319.

55 T. 201 (IV) 293c3-297c10, trans. Huber 1908: 192-210. The title might also have been understood more fully as Kalpanāmaṇditikā Drșțāntapankkti, for which Loukota Sanclemente suggests "Garland of Examples Adorned by Poetic Fancy"; see 2019: 64 for his discussion of the title. Nota bene: the same story being found in many sources, including in Pāli, casts significant doubt on the suggestion of Loukota Sanclemente 2019: $141 \mathrm{n}_{174}$ that the story of Nìtha is an "original invention of Kumāralāta." Likewise I do not understand his mention (p. 177) of "Kumāralāta's vehement defense of the caṇdāla," which I at any rate cannot detect. 
of which has recently been reexamined by Loukota Sanclemente, ${ }^{56}$ who calls it (p.131) "one of the longest and most elaborate stories in the collection." Here the main character Nitha is a cleaner of filth (穓檅人). ${ }^{57}$ The Tathāgata is praised (295a20-21, Huber 1908: 200) as one who examines hearts, not paying attention to caste, and somewhat later the Buddha himself proclaims $(295 \mathrm{c} 6-7$, Huber 202) that he does not observe caste or high or low status, but only one's previous deeds. Proclaiming that he preaches equally to all, he then says (295c2425, Huber 203) that like pure water (see above n. 9) his teaching is available equally to brāhmaṇas, kṣatriyas, vaiśyas and suudras. Nìtha too is ordained and becomes an Arhat (296b8, Huber 206). This is where the text gets interesting (296b8-15) for, as we just saw above in the Śärdülakarṇāvadāna, there is strong opposition. The brāhmana elders of the town, hearing about the ordination, fear that one of mean status, coming to beg, will sully their homes. ${ }^{58}$ They complain to king Prasenajit, who promises them that he will request the Buddha not to grant ordination to the low caste person. However, when the king arrives and encounters a monk, he does not recognize that this is the very same Nitha who so concerns the townsmen and him (296b25). The story continues in some detail, and the king eventually acknowledges (296c26) that all castes can equally attain spiritual fruits, and here too (296c29-297a2) we find an expression we have encountered above, namely that caste applies in matters of marriage (婚娶) but not in the Buddha's teaching, ${ }^{59}$ and persons are like different woods that burn in the same way (see n. 39, above). The same basic story is recounted briefly also in Pāli, in the commentary to the Theraga $\bar{t} t h \bar{a}^{60}$ where the main character Sunita (obviously related to Sanskrit Nitha) gathers spoiled and wilted flowers from shrines, the Buddha ordains him with the ehi

$56 \quad$ Loukota Sanclemente 2019: 131-138.

57 The name is attested in Schøyen Brāhmī MS 2382.318 A, recto 2, edited in Loukota Sanclemente 2019: 352, and discussed p. 354 .

58 This portion is preserved in Schøyen Brāhmī MS 2379.5, recto 2-3, edited in Loukota Sanclemente 2019: 357-358, where we find /// .. samiv[r] tah pravrajitam ca nïtham äjñāya śrāvastakā brāhmaṇagrhapataya $k s ̣(o) b d h(u) . .$. /// (r 3) /// (visar)j(a)yati vițvālitany asmākam grōanni dūṣitāni ca śayanāsanāni yatra śramaṇāh ///. The Chinese text of T. 201 (IV) $296 \mathrm{~b} 8-\mathrm{c} 23$ is translated pp. $360-363$.

59 See the passage cited above from the Kunālāvadāna. Here 296c29-297a2: 若婚娶時, 取 四種姓。此四種姓皆可得淨。若娶取婦嫁女, 應擇種姓。此佛法中, 唯觀宿世 善惡因縁, 不擇種姓。

6o Th-a ii.262-265, trans. Rhys Davids 1913: 271-274, on Theragāthā 620-631. In Theragāthā 620 , Sunīta says "I was born in a low family, poor, having little food; my work was lowly-I was a disposer of (withered) flowers," nīce kulamhi jāto 'ham daliddo appabhojano | hìnam kammam் mamam் āsi ahosim pupphachaḍdako. Trans. Norman 1969: 62. 
bhikkhu formula (ii.263,1; 28), and Sunìta gains great spiritual fruits. Finally, we should note the version of the same story found in the Chuyao jing 出矅經, a commentary on the Dharmapada ${ }^{61}$ in which the central character is explicitly a candâala. The Buddha ordains him (710a22) and he quickly attains spiritual fruits, up to arhatship. Once again, Prasenajit hears that a candāla has been ordained, and worries. He thinks (710a29-b4) that the Buddha himself comes from the Sankya clan, and the monks from all four castes, but now that someone from the candāla caste (旃陀羅種) has been ordained, how are we to bow to him? However, upon visiting the Buddha he encounters the very monk who concerned him, learns that he has attained supernatural powers, and in the end is satisfied.

These are not the only stories of the ordination and spiritual attainment of a caṇ̂āla. In the Karmaśataka, we read that Kātyāyana ordained a candāla, instructed him, and this candāla attained arhatship. ${ }^{62}$ In a story of the past explaining the present situation, it is narrated that in a previous life this same individual was a canda âla who became a monk, but being quarrelesome became angry at a group of many monks and called them "canda ăla," which however he quickly repented. However, as a karmic result of his calling that group of monks "candāala," he was reborn 500 times as a caṇ̂ăla. ${ }^{63}$ Another example comes from a story in the Kalpanāmanditika of a canḍala executioner. A crisis occurs because the candăla refuses further to act as an executioner. Ultimately, after killing almost everyone in his quest for obedience, the king says: 64

People of the world examine one's caste, they do not examine whether internally one upholds the rules of restraint.

61 T. 212 (IV) 709c28-71ob28; Miyasaka 1992: 94-96. Note however that the Indian bona fides of the Chuyao jing as a collection are questionable; Hiraoka 2007b suggests that despite a preponderance of Sarvāstivāda materials, the collection as a whole also contains matter from other sectarian sources, suggesting it as a Chinese compilation (I do not know whether there exist any Indian compositions with material from different lineages mixed together). This does not, however, imply that the stories it contains are not themselves Indian, only that the arrangement of diverse materials took place elsewhere. I thus feel confident citing it here as Indian evidence.

62 Story v.5, summary in Feer 1910: 300, trans. Lozang and Fischer 2020: 5.83-95. The text is in $\mathrm{D} 340$, mdo sde, ha, 214 $\mathrm{b}_{5} \mathrm{ff}$.

$63 \quad \mathrm{D} 340$, mdo sde, ha, 216a7, 216 3 -4.

64 T. 201 (IV) 299a6-12: 世人觀種族不觀内禁戒/護戒爲種族設不護戒者/種族當滅 壞我是斿陀羅 / 彼是淨戒者彼生斿陀羅 / 作業實清淨我雖生王種 / 實是旃陀羅 我無悲㟲心 / 極惡殺賢人我實斿陀羅. Trans. earlier by Huber 1908: 219. 
[But actually] keeping the rules of restraint constitutes one's caste. One who does not keep the rules of restraint

Destroys his caste. It is I who am a caṇ̂ala.

Those persons purely upheld the rules of restraint, [though] they were born as canḍ̂las.

Their actions were truly pure. Though I was born in the royal caste,

I am truly a caṇ̂āla. I lack a compassionate heart,

Extremely evil, I killed noble men-I truly am a caṇ̣̂āla.

In the same text, elsewhere we find the expression that a candāla was a learned upāsaka and had obtained the darśanamārga, the third of five landmarks toward spiritual perfection. ${ }^{65}$ Clearly, then, here in the narrative tradition, even if it is limited and mono-typical, we find examples which portray candâlas as capable of spiritual attainment. The evidence of such passages must be acknowledged, and given full weight. They suggest the existence of an attitude of openness and lack of discrimination against even the lowest of the low. This cannot be denied.

At the same time, despite the evident importance of such passages, almost everywhere else in Indian Buddhist literature, no matter where we look, we encounter, on the contrary, considerable evidence of the nearly uniform fashion in which these texts display an intense antipathy toward candâlas. Some of these instances are quite explicit and perhaps self-conscious, while others seem rather to demonstrate a tacit and even subconscious attitude.

It is clear that for those who composed almost all varieties of Indian Buddhist texts, the examples cited above aside, it is very bad indeed to be a candāla. The Pāli Vinaya speaks of two kinds of birth, inferior and superior, in the following terms: ${ }^{66}$ "There are two kinds of birth: inferior birth and superior birth. Infe-

65 T. 201 (IV) 298b18: 彼斿陀羅是學優婆塞得見諦道. See Huber 1908: 217.

66 Vin. iv.6,9-12: jāti nāma dve jātiyo: hīnā ca jāti ukkațthā ca jāti | hīnā nāma jāti: candâalajāti venajāti nesādajāti rathakārajāti pukkusajāti | esā hīnā nāma jāti. ukkaț̣hā nāma jāti | khattiyajāti brāhmanajāti | esā ukkaț̣hā nāma jāti. This first sort of listing is found right up through the tantric literature. For instance, see the Dafaju tuoluonijing 大法炬陀羅尼經 (T. 1340 [XXI] 666a22-24), in which the list includes canda ạlas, evil magicians (惡呪師家), butchers, bamboo workers, trappers and birders. 
rior birth is birth as an outcaste (candāala), birth as a bamboo-worker (vena), birth as a hunter (nesāda), birth as a cartwright (rathakära), birth as a scavenger ( $p u k k u s a)$. This is inferior birth. Superior birth is birth as a khattiya, birth as a brāhmana. This is superior birth." In case there were any lingering doubts about how these were imagined, such doubts would be removed by a passage in the Majjhimanikāya in which we find a description of what happens after the very negative rebirth in the unfortunate realms (vinipāta =duggati) of a fool who does not practice the Teaching: ${ }^{67}$

67 MN iii.169,25-170,6: sa kho so bhikkhave bālo sace kadāci karahaci dīghassa addhuno

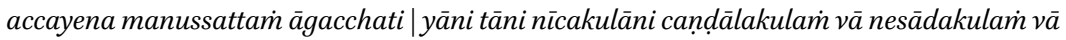
venakulam vā rathakārakulaì vā pukkusakulam vā | tathārūpe kule paccājāyati dalidde appannapānabhojane kasiravuttike | yattha kasirena ghāsacchādo labbhati | so ca hoti dubbaṇno duddasiko okoțimako bahvābādho kāṇo vā kuṇi vā khujjo vā pakkhahato vā na lābhī annassa pānassa vatthassa yānassa mālāgandhavilepanassa seyyāvasathapadīpeyyassa | so kāyena duccaritam carati vācāya duccaritam carati manasā duccaritam carati | so kāyena duccaritam caritvā vācāya duccaritaṁ caritvā manasā duccaritam caritvā kāyassa bhedā param maraṇa apāyam duggatim vinipātaṁ nirayaṁ upapajjati. Trans. Ñāṇamoli 1995: 1021. (See also T. 26 [199] [I] 761c13-22.) Almost precisely the same passage is found for instance in SN i.93,28-94,13; AN ii.85,15-15, iii.385,7-18. This last passage is presented as part of the Buddha's response to Pūrana Kassapa, who claimed (AN iii.383,22-25): kaṇhābhijāti pañnattā orabbhikā sūkarikā sākunikā māgavikà luddā macchaghātakā corā coraghātakā bandhanāgārikā ye vā panaññepi keci kurūrakammantā, namely that the "black class" of beings includes various butchers, hunters, and other killers. The Buddha here thus seems to reject the idea that one's livelihood places one into a certain category. Jha 1974a: 78 seems to have misunderstood the passage. Note that in contrast similar listings of low births are indeed not uncommon, and precisely the same terminology of "black class" is found for instance in the Yogācārabhümi (Bhattacharya 1957:

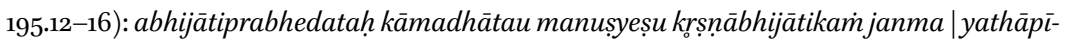
haikatyaś caṇdālakuleșu vā pukkasakuleșu vā rathakārakuleșu vā veṇukārakuleșu vā itiyāni vā punar anyāni nīcāni adhamāni krcchrāṇi krrcchravrttīni parìttāni parīttānnapānabhojanāni ity evamiūpeșu kuleșv abhijāto bhavati $\mid$ ta eva manușyadurbhagā ity ucyante $=\mathrm{T}$. 1579 (xxx)32ob28-c3: 勝生差別者, 謂欲界人中有三勝生。一, 黑勝生生, 謂如有一 生斿茶羅家、若卜羯娑家、若造車家、若竹作家、若生所餘下賤、貧窮、 乏少財物、飲食等家。如是名為人中薄福德者.

We find the same idea in the Pañcavimśatisāhasrikā Prajñāpāramitā, directed against those who reject the profound Perfection of Wisdom (Kimura 1986:151.19-25): te bahuduhkhavedañ̄yam karma kșepayitvā kadācit karhicit mānușyakam ātmabhāvaṁ pratilapsyante | te yatra yatropapatsyante tatra tatra jātyandhā bhavișyanti |jātyandhakuleșūpapatsyante | caṇdāalakuleșu vā pușkasakuleșu vā śākunikuleșu vā sukarikuleșu vā aurabhikakuleșu vā nīceșu vā kutsiteșu vā kuleșu vā nīcavrttisu vā upapatsyante | te teșūpapannā andhā vā bhavisyanti kānā vā ajihvā vā ahastā vā apādā vā akarnakā $v \bar{a}$ anāsikā vā. See the (somewhat abbreviated) trans. in Conze 1975: 289. Almost the same at Kimura 1992: 30.19-25; trans. Conze 1975: 454 . 
If sometime or other at the end of a long period, that fool comes back to the human state, it is into a low family (nicakula) that he is reborn-into a family of outcasts (canḍāla) or hunters (nesāda) or bamboo-workers (vena) or cartwrights (rathakära) or scavengers (pukkusa) —one that is poor with little to eat and drink, surviving with difficulty, where he scarcely finds food and clothing; and he is ugly, unsightly, and misshapen, sickly, blind, cripple-handed, lame, or paralyzed; he gets no food, drink, clothes, vehicles, garlands, scents and unguents, bed, lodging, and light; he misconducts himself in body, speech, and mind, and having done that, on the dissolution of the body, after death, he reappears in a state of deprivation, in an unhappy destination, in perdition, even in hell.

This kind of list of the "low" - typically including at least candālas, bambooworkers, cartwrights, and pukkasa - is frequently met with, and plainly refers to a grouping of those who stand outside the norms of acceptable society. 68 It appears for instance in slightly flexible stock description of unfavorable rebirths that might be the result of evil actions, placed together with various bodily infirmities - we would call them, politically correctly, handicaps or disabilities - among which being born ugly is a common member of the list. ${ }^{69}$ Evil deeds lead to this result, and some authors use this opportunity to insert

68 Their use as terms of aspersion is evident in verses of the Kuśa Jātaka found both in Pāli and in the Mahāvastu, which, although slightly differently cast, make the same point. In Pāli (verses 57-58, Jāt. v.3o6,14-22) we find the character Pabhāvatî’s mother accus-

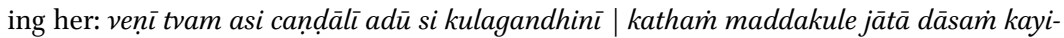
rāsi kāmukan ti, "You are a bamboo-worker, canḍālū, a destroyer of this family! Born into Madda's household, how could you make a slave your lover?” She replies: $n$ 'amhi veñi na caṇdālì na c 'amhi kulagandhinī | okkākaputto bhaddan te tvaṁ nu dāso ti maññasì ti, "I am no bamboo-worker, no cand $\bar{a} \bar{l} \bar{\imath}$, no destroyer of this family! If you please, he is the son of [king] Okkāka [= Kusa], whom you think a slave!" In the Mahāvastu parallel we find the grammar altered, and the subject Kuśa, not the maiden: ko nu veño va pānno vā atha vā puna pukkaso | kasya rājakule jāṭo kasya kurvami adhomukham, "Is he a bamboo-worker, a pāna [?], or a pukkasa? Is he of royal birth? Whom does he serve?" [I here follow Marciniak 2019: 29n4]. Then the character Sudarśanā answers saying: na eșa veṇo na caṇ̣̂ālo atha vā puna pukkaso | putro ikșvākurājasya tam tvam dāso ti manyasi, "He is no bamboo-worker, no candāla, nor a pukkasa. He is a son of the Ikșvāku king, the one whom you think to be a slave." For the text see now Marciniak 2019: 29.4-8. (Note that translations including Jones 1949-1956: III.2O misunderstand vena as "musician.") Given the reply, it is hard to understand both pāna and the absence of $d \bar{a} s a$; see in addition to Marciniak's notes the considerations of Chopra 1966: 134 (and see p. 181).

69 The topic of physical (what we would now call) handicaps or disabilities in Indian Buddhism is seriously understudied. See for a start Kusama 1989 . 
their quite specific dislikes. ${ }^{70}$ As one example, for the Lañkāvatārasūtra, ${ }^{71}$ "[A meat eater is] born again and again among the candālas, pukkasas and dombas as evil-smelling, offensive, and insane." In listings of dangers and threats, for instance to travelers, we find the same general idea. In Perfection of Wisdom scriptures, a person, having walked through a forest, upon seeing a town is no longer afraid: "He may take a deep breath and there is no longer any danger of robbers, of candālas, of fierce beasts, of hunger or of thirst."72 The Ugradattapariprccha presents much the same idea of the dangers lurking in a wilderness: $: 3$

70 As one example of a rather generic but quite clear cause and effect relation, see the passage from the Śäriputra Repentence Sütra, Shelifu huiguojing 舍利弗悔過經: “If there are good men and good women who do not desire to enter into the states of hell-dwellers, animals, or hungry ghosts, they should repent all of their transgressions and should not conceal them. After they have undertaken the precepts, they should not do evil again. If they do not desire to be reborn in borderlands without a buddha, without the teaching, without a community of monks, without righteousness, in a place [defined by distinctions between] good and evil, they should repent all of their transgressions and should not conceal them. If they do not wish to be stupid, deaf, blind, or mute, if they do not wish to be born as butchers, fishermen, jailors, or reborn into poor families, they should repent of all their sins and should not conceal them." T. 1492 (XXIV) 109ob18-24: 若有善男子善女 人, 意不欲入泥犁、禽獸、薜芬中者, 諸所作過, 皆當悔之, 不當覆藏, 受戒以後, 不當復作惡。不欲生邊地無佛處、無經處、無比丘僧處、無義理處、善惡 處者, 皆當悔過, 不當覆藏。意不欲愚癡、聾、盲瘖瘂、不欲生屠生、漁獵、 獄吏更生貧家, 皆當悔過不當覆藏. In the otherwise apparently unknown Pravrajya ntarāyasūtra quoted in the Śikșāsamuccaya (Bendall 1897-1902: 69.5-7; Cambridge Add. 1478 40a3), a householder who acts wrongly (in ways which the passage enumerates) will suffer in various unsavory rebirths: "He will be born blind, stupid, dumb, a caṇ̂ala, never happy. And he will be often slandered, will be impotent, queer, an eternal slave, and he will be a woman, a dog, a pig, a donkey, a camel, and a poisonous snake in birth after birth," jātyandhaś ca jậdaś cājihvakaś ca caṇdālaś ca na jātu sukhito bhavaty abhyākhyānabahulaś ca șaṇdakaś ca paṇdakaś ca nityadāsaś ca | strī ca bhavati śvā ca śūkaraś ca gardabhaś coștraś cāsívișaś ca bhavati tatra tatra jātau. (On the sexual vocabulary see the detailed study of Cabezón 2017, esp. 373-451.)

71 Nanjio 1923: 257.16-258.1, 8.14 (quoted also in the Śikșāsamuccaya, Bendall 1897-19o2: 132.18-133.1): durgandhikutsanīyaś ca unmattaś cāpi jāyate | caṇḍālapukkasakule dombeșu ca punah punaḥ.

72 Kimura 1990: 17.13-15: sa āśvāsaprāpto bhavet | na cāsya bhūyo bhavati caurabhayaì vā caṇ̣̂ālabhayam vā caṇ̣̂mrgabhayam vā bubhukșābhayam vā pipāsābhayam vā; cp. Conze 1975: 322. A similar listing of dangers is found at Kimura 1990: 51.15-16: yena caurabhayam caṇdālabhayam lubdhakabhayam caṇdamrgabhayam āścivișabhayam kāntārāțavibhayaim durgabhayam; Conze 1975ः 342: danger from robbers, outcastes, desperadoes, fierce beasts, vipers, wild jungles, and treacherous roads. Similar passages could be easily multiplied.

73 Quoted in the Sikșāsamuccaya, Bendall 1897-1902: 198.1-6: punar aparam gŕmapate pravrajitena bodhisatvenāranye prativasataivam upaparīkșitaryam | kimartham aham 
Moreover, O Eminent Householder, the renunciant bodhisattva who lives in the wilderness should reflect as follows: "For what reason do I live in the wilderness? Wilderness-dwelling alone does not make one a śramana. There are many living here who are not tamed, not disciplined, not restrained, not intent, such as deer, monkeys, flocks of birds, thieves and candāalas. And they do not possess the qualities of a śramana. So for what reason do I live in the wilderness? Namely, it is so that I might fulfill the aim of the śramana."

It is in fact quite common that birth as a canda a la is characterized as low, and candālas are considered fearful, together with wild beasts and robbers. ${ }^{74}$ The location of such beings signals danger. In a stock expression, found widely in the Vinaya and śāstric literature, for instance in the Śrāvakabhümi, there are five places a monk should not go. Although the first item is not entirely clearit might refer to a musician or a butcher- the remaining four places prohibited to monks are a brothel, a bar, a royal palace, and a cand $\bar{a} l a$ 's hut. ${ }^{75}$ Leaving aside the many interesting questions raised by this list, it is clear that the candāla

aranye prativasāmi $\mid$ na kevalam aranyavāsena śramaṇo bhavati | bahavo 'py atrādāntāvinïtāyuktānabhiyuktāh prativasanti $\mid$ tad yathā $\mid$ mrgavānarapakșisamighacauracand lāh prativasanti $\mid$ na ca te śramaṇaguṇasamanvāgatā bhavanti $\mid$ api tu khalu punar aham yasyārthāyāranye prativasāmi sa mayārthạ paripūrayitaryo yad uta śrāmaṇyārthaḥ. The trans. is mine, but based on that of Nattier 2003: 291, §25A, who did not translate the Sanskrit.

74 In a passage from the Perfection of Wisdom, a bodhisattva who trains correctly is freed from nasty rebirths, listed as (Conze 1962: 41.17-21; trans. Conze 1975: 454) naraka, tiryagyoni, yamaloka, pratyantima janapada, pukkasa-caṇ̂ălakula, nor is one one-eyed, humpbacked, lame, crippled (?), deaf, sunken in mud (?), or handicapped, kāna, kubja, lañga, ūnānga, badhira, paìkapatita, vikalendriya.Jens-Uwe Hartmann kindly drew my attention to the passage in a Schøyen manuscript (the name of the text is unknown) at Harrison, Harmann and Matsuda 2016: 290-291 which has caṇḍala, pukkasa, venukāra ... andha, kāṇa, kubja, kalla, lamgga, badhira, pakșahata.

75 Śrāvakabhūmi Study Group of Taishō University 1998: 66, (I)-C-IIl-4-a-(1)-iv; D.17a3-5; T. 1579 (XXX) 402c15-20 (cp. 368a28-b3): katham ca gocarasampanno bhavati | pañca bhikșor agocarāh | katame pañca | tadyathā ghoṣo veśyam pānāgāro rājakulam caṇdālakațhinam eva pañcamam iti | ya etāìns tathāgatapratikșiptān agocarān varjayitvānyatra gocare caraty anavadye tatra kālenaivam gocarasampanno bhavati. see Śāvakabhūmi Study Group of Taishō University 2007: 337-368, and (I)-C-IIl-8-a-(3)-i; D.48a2; T. 1579 (Xxx) 415b25-27. Basically the same listing is also found, to name only a few sources among many, briefly in the Mūlasarvāstivāda Vinaya (T. 1442 [XXIII] 689c2-4; 733a2o-21; 79oa1517; T. 1451 [XXIV] 381a12-14), Sarvāstivāda Vinaya (T. 1435 [XXIII] 359b17-25) and Abhidharmasamuccayabhāsya (Tatia 1976: 71.15-17; Bayer 2010: 258): gocarasamipannah pañcāgocaraparivarjanāt | pañca bhikșor agocarāḥ | ghoșo veśạ pānāgāraṁ rājakulam canḍālakațhinam eva pañcamam. In Tibetan, D 4053, sems tsam, shi 205a7-b1, the word ghoșa is 
represents a danger to the serious practitioner. The same holds for the Saddharmapundarika, in which it is stated that a bodhisattva should avoid a great many undesirables, including the candāla: ${ }^{76}$

rendered gsod pa'i sa, killing place. There are other instances of the stock expression with slightly different wordings.

The first term, ghoșa, is difficult. When the list above is repeated at T. 1579 (xxx) 368a28-b1, ghoșa is defined as follows (T. 1579 [xxx] 368b1-3): 唱令家者, 謂: 屠羊等。 由遍宣告, 此屠羊等, 成極重罪。多造惡業, 殺害羊等故, in Tibetan (D 4035, sems tsam, dzi 215b7-216a1): sha 'tsong gi gnas ni gsod pa'i gnas yin par blta bar bya ste | der 'bod cing shan pa byed pa la sogs pas shin tu kha na ma tho ba sdig pa'i las lug la sogs pa gsod par byed pa'o. Here butcher or some other kind of killer is the operative understanding. (See also the Yugaron ki 瑜伽論記 by the early 8th c. Korean Tullyun 遁倫 [T. 1828 (XLII) 418c4-19].) The word is also glossed in Huilin's 慧琳 Yiqiejing yinyi一切經音義 (T. 2128 [LIV] 622C11-12): 唱令家: 上 [鳽-开+幺] 讓反。謂作音樂人、戲作人也。又云尋 香人也。是等家無産業唯乞自活。若見有飲食處, 即徃至彼爲設倡伎求財食也. This glossary, which in this case seems to transmit a meaning also found in Indian sources, suggests the meaning of "musician." The word is discussed by Bayer 2010: 409n386, without reference to either of these sources, but with notice of both possible meanings (as well as several other ideas). Other of Bayer's notes here briefly discuss the other four terms as well. I am not totally convinced by the suggestion of Ujike 1985:3 that the five places should be connected to the pañcaśila.

Peter Szántó draws my attention to Turner 1966: $\$ 45^{28}$, which identifies Prakrit ghōsa (semantically similar to Sanskrit goștha) in the sense of "cowherd's station," a meaning found also for Sanksrit ghoṣa and Pāli ghosa, Szántó then suggesting that this was a place where animals were killed.

76 Saddharmapundarīka XıII §8-9, verses 1-12, cited following the Gilgit/Nepalese recension edited by Karashima 2003 (see also Silk 2001: 93 for the citation in the Śikșāsamuccaya).

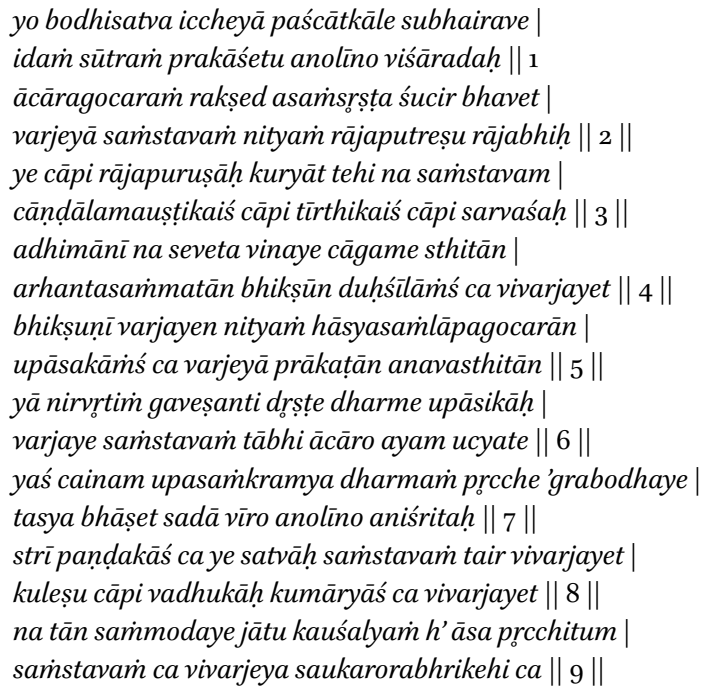


A bodhisattva who, bold, uncowering, would wish to preach this sūtra in an extremely fearful future time should keep to proper practices and should be undefiled and pure. He should constantly avoid familiarity with princes and kings, and should not be familiar with royal servants either, nor with canḍālas, wrestlers (?), non-Buddhist sectaries, anywhere at all. He should not serve those who are arrogant about their fidelity to the Monastic Rule and the Teachings, and should stay away from monks who, while considered to be Saints, are [actually] ill-behaved. He should constantly avoid nuns given to laughter and chit-chat, and should avoid vulgar, fickle female lay-followers. He should avoid familiarity with those female lay-followers who seek liberation in the here and now-this is called [proper] practice. But he, being brave, uncowering, truly free, should always preach to a man who would approach him and ask about the Teaching for the sake of the highest Awakening. He should shun familiarity with women and hermaphrodites, and should shun young women and maidens in families. He should never converse with them to ask after their well-being, and should avoid familiarity with pig and sheep butchers. He should shun familiarity as well with those who take life in various forms in order to make a living, who sell meat at a slaughterhouse. He should avoid familiarity with pimps, and with dancers, fighers and wrestlers, ${ }^{77}$ and such like. He should not serve madams and others in the pleasure business, he should thoroughly avoid any sort of communication with them at all.

This type of expression is found in other genres of literature as well. The dhāranī sūtra Dabao guangbo louge shanzhu mimi tuoluonijing 大寶廣博樓閣善住祕密 陀羅尼經, for instance, states that those who uphold the dhäranī will be free of poverty, and not harmed by dangers such as poisons, weapons, fire or water and the like. Wild animals will not attack them, and there will be no thieves

ye cāpi vividhāim prāṇìm himseyur bhogakāraṇāt | māmsaì sūnāya vikrenti samistavaim tair vivarjayet || 10 ||

strīpoșakāś ca ye satvā varjayet tehi samistavam | națai jhallakamalleșu ye cānye tādrśā bhavet || 11 || vāramukhyā na seveta ye cānye bhogavrttayah | pratisammodanām tehi sarvaśa ḥ parivarjayet || 12 va Dharmaśāstra (Ed. and trans. Olivelle 2005) 12.45ab: jhallā mallā națāś caiva puruṣāś ca kuvrttayah, "Jhallas, Mallas, Națas, men who live by vile occupations ...." The terms occur together also in 10.22 . 


\section{or robbers or candālas. ${ }^{78}$ The text goes on that they will be free of dangers while traveling, from a variety of diseases, and so on. ${ }^{79}$ A clearly tantric text, the}

78 The text adds: or nanmo 喃摩; I do not know the meaning of this evident transcription.

79 T. 1005a (XIX) 622c5-7: 離於貧窮, 不受世間毒藥、刀杖、水火等難。諸惡獸怖不 能爲害。無諸賊怖, 無劫盗怖, 無旃陀羅怖, 無喃摩怖. This was referred to by Matsunaga 1991: 271. A type of restriction similar to that in the Saddharmapundarīka is found with regard to mantra practitioners, for instance, in the Pinaiye jing 毘奈耶經 (the Indian origins of which are not clear to me, hence I cite it here in a note), in which we read that "One who recites the mantras should not approach a place of thieves, prostitutes, widows, candālas, dangerous beasts, or poisonous snakes, nor the houses of leather workers, pork and mutton butchers, and places where camels, donkeys, boars, dogs, chickens, or hawks are raised to be hunted, nor charnel grounds, nor the homes of physicians or nonBuddhist sectaries — the mantra reciter should absolutely not dwell in such places," T. 898 (XVIII) 773b28-c2: 若有賊難、婬女、寡婦、旃陀羅、惡獸、毒蛇之處, 及作皮靴 家、屠兒魁膾家、養駝、驢、猪、狗、雞、鷹遊獵之家, 亦不近塚間, 醫師、 外道家, 如是等處, 誦持呪者, 悉不應住.

Although I do not systematically consider tantric literature here, it is worthwhile noting that tropes similar to those in other Buddhist literature abound. Matsunaga 1991 cites a great number of passages in which, for instance, it is prohibited to eat together with caṇ̂̄ālas, in which seeing a caṇ̂ăla in a dream is inauspicious, and so on, but others which are, or superficially seem, much more positive and accepting. In general, since the more antinomian tantric rhetoric can introduce complications, for the present I leave consideration of these materials aside, in the hope that a specialist will undertake a good survey. Matsunaga 1991 is no doubt a start, but not more than that. In this regard, see also Aktor 2016; Shizuka 2001, the latter concerning a passage treated by Szántó 2012: 336-338.

Potential complications aside, it is possible that we should best understand much of this literature (also) in a context which shows it ultimately to align with our other materials. In this light, I cite a single example in which it is abundantly clear, once again, that the canda a la is emblematic of the lowest of the low, a short series of verses from the Guhyasamäjatantra (Matsunaga 1978: 15.9-20, vss. V.2-7):

Candālas, bamboo workers and the like, those who have their minds set on killing, succeed here in the highest vehicle, the unexcelled Mahāyāna. 2

And those too who commit terrible sins, beginning with the [five] sins of immediate retribution, succeed here in the Buddha vehicle, the ocean of the Mahāyāna. 3

Those most intent on blaming their teachers will never succeed in their practice. But those beings who take life, who delight in telling lies, 4

And those who delight in the possessions of others, and always delight in lust, who consume piss and shit, they indeed are fit for [this] practice. 5

And the practitioner who would sexually enjoy mother, sister or daughter would fully attain complete perfection, the ultimate reality of the Mahāyāna. 6

Desiring the mother of the lord, the Buddha, he is not attached to [her]; that wise one, free from conceptual thought, succeeds [in attaining] buddhahood. 7

caṇ̣̂ālavenukāāādya māraṇārthārthacintakāḥ|

sidhyanti agrayāne 'smin mahāyāne hy anuttare $\|_{2}$

ānantaryaprabhrtayo mahāpāpakrto 'pi ca|

sidhyante buddhayāne 'smin mahāyānamahodadhau || 3 
Jingang kongbu jihui fangguang guiyi guan zizai pusa sanshi zuisheng xinming wangjing 金剛恐怖集會方廣儀軌觀自在菩薩三世最勝心明王經, emphasizes the inauspiciousness of the candāla as follows: 80 "If one does not obtain the siddhi, he will dream of caṇ̂ălas, piśācīs or [other] evilly shaped creatures, or he will see persons wearing soiled and ruined clothing, or he sees the mantra, but it is missing some of the words, or he sees crippled persons." The point here should be clear, namely that canda $\bar{l}$ las are an expected part of the negative and indeed dangerous landscape, both physical and metaphorical, and strictly to be avoided and indeed feared.

This assumption of the extreme baseness of the candāla is emphasized by his use as a register of the supreme achievements of the bodhisattva. The Ratnameghasūtra says that, "Just as [bodhisattvas] teach kings and high ministers, they also teach candālas and young candālas, to say nothing of [teaching] others [such as] townsmen and provincials. But through this offering of the Teaching they do not become arrogant; in just this way, good man, the bodhisattva becomes complete in his offering of the Teaching." ${ }^{81}$ Similarly, "How is the bodhisattva's unrivaled non-discriminative tolerance (kșānti) complete? Although some are tolerant toward father, mother, master, wife, son, daughter, relatives, and kinsmen, but impatient with others, the bodhisattva is patient even as far as toward young candālas. In just this way, the bodhisattva's unrivaled non-discriminative tolerance becomes complete." ${ }^{\prime 2}$ In a

ācāryanindanaparā naiva sidhyanti sādhane | prānātipātinaḥ sattvā mrșāōōadaratāś ca ye $\| 4$ ye paradravyābhiratā nityam kāmaratāś ca ye | vinmūtrāhārakrtyā ye bhavyās te khalu sādhane $\| 5$ mātrbhaginīputrīś ca kāmayed yas tu sādakah | sa siddhim vipuläṁ gacchen mahāyānāgradharmatām $\| 6$ mätaram buddhasya vibhoḥ kāmayan na ca lipyate | sidhyate tasya buddhatvam nirvikalpasya dhimatah $\| 7$

80 T. $1033(\mathrm{xx}$ ) 14b27-29: 若失成就。夢旃陀羅、毘舍遮鬼、惡形状者, 或見人身著垢 弊衣,或見眞言文句關少。或見不具足人.

81 Thanks to the generosity of Vinītā Tseng, I can cite the Sanskrit here (7b6): yathaiva rājño rājamātrasya vā samprakāśayati | yathaiva caṇ̂āa lasya vā caṇ̣̂ālakumārasya vā samprakāśayati | kah punar vādas tadanyeșāmi naigamajānapadānām na ca tena dharmadānenonnato bhavaty evam hi kulaputra bodhisatvo dharmadānasampanno bhavati. D 231, mdo sde, wa 11b7-12a2: ji ltar rgyal po'am blon po chen po la yang dag par ston pa de ltar gdol pa'am $\mid$ gdol bu la yang yang dag par ston na $\mid$ de ma yin pa grong pa dang $\mid$ yul gyi mi gzhan dag la lta ci smos | chos kyi sbyin pa des khengs par yang mi 'gyur te | rigs kyi bu de Itar na byang chub sems dpa' chos kyi sbyin pa phun sum tshogs pa yin no.

82 The sūtra manuscript reads (11a7-b1): kathaì ca bodhisatvo nānākșāntisaminanno bhavati | iha bodhisatvo na mātāpitrgurubhāryāputraduhitrjñātisālohitānām kșamate | anyeșām na kșamate | kin tarhi bodhisatvo antaśaś caṇdālakumārakasyāpi kṣamate | evam 
final example from the same text, we read, "How does a bodhisattva treat all beings equally? Good man, take fire as an example: it treats all beings equally. As it provides service to a king, just so it does the same to a candâala. In this manner a bodhisattva too treats all beings equally, and he provides service to a king just as he does to a candūala. In just this way, the bodhisattva treats all beings equally." 83 Such examples demonstrate that the candāala serves as a pole, at the very most negative extreme, and the fact that the bodhisattva is equally open to him is a mark of his transcendence. In other words, the category of candāla is deployed in such instances to emphasize the extreme (we might say superhuman) abilities of the bodhisattva, thereby emphasizing the-once again, extreme-baseness of the candāla.

hi bodhisatvo nānātvakșāntipratipanno bhavati. Dr. Tseng edits this as follows: katham ca bodhisatvo 'nānātvakșāntisampanno bhavati? iha bodhisatvo na mātāpitrgurubhāryāputraduhitrjñātisālohitānām kșamate 'nyeșām na kșamate. kim tarhi? bodhisatvo 'ntaśaś, caṇdālakumārakasyāpi kșamate. evam hi bodhisatvo 'nānātvakșāntisamianno bhavati. The na after iha bodhisatvo is, I believe, to be deleted, though I note that Dr. Tseng disagrees, pointing to the Tibetan translation, which in other respects has guided my translation: D 231, mdo sde, wa 17b4-5: ji ltar na byang chub sems dpa' tha dad pa med pa'i bzod pa phun sum tshogs pa yin zhe na |'di la byang chub sems dpa' pha dang | ma dang bla ma dang bu dang bu mo dang chung ma dang nye du 'am snag gi gnyen mtshams la bzod la | gzhan la mi bzod pa ma yin gyi | byang chub sems dpa' ni tha na gdol pa gzhon nu yan chad la yang bzod de | de ltar na byang chub sems dpa' tha dad pa med pa'i bzod pa phun sum tshogs pa yin no. Cp. Dharmachakra Translation Committee 2019: 1.96. T. 658 (XVI) 214a48 words things slightly differently, but with the same gist: 云何名菩薩修處處忍。有 人於父母、師長、夫妻、男女、大小、内外, 如是中生忍, 餘則不忍。菩 薩忍者, 則不如是。如父母邊生忍, 斿陀羅邊生忍亦爾。是名菩薩修處處忍. Dr. Tseng understands that "Here a bodhisatva does not patiently accept his mother, father, preceptor, wife, son(s), daughter(s), relatives and kinsmen, to the exclusion of the others."

83 Dr. Tseng kindly again shared her transcript (26b7-27a1): katham ca bodhisatvah sarvasatvasādhāraṇo bhavati | tadyathāpi nāma kulaputra tejạ̣ sarvasatvasādhāraṇam yathaiva rājña upakāreña pratyupasthitam bhavati | yathaiva [> tathaiva] caṇḍalakumārasyāpi | evam eva bodhisatvaḥ sarvasatvaḥ sādhāraṇo bhavati | yathaiva rājña upakāreña pratyupasthito bhavati | tathaiva caṇ̣̂ālakumārasyāpi | evam hi bodhisatvah sarvasatvasādhārano bhavati. D 231, mdo sde, wa 41b2-4: ji ltar na byang chub sems dpa' sems can thams cad kyi thun mong du gyur payin zhe na | rigs kyi bu'di lta ste | dper na me ni sems can thams cad kyi thun mong du gyur pa ste |ji ltar na rgyal po la phan par nye bar gnas pa ltar gdol bu la yang de bzhin no || de bzhin du byang chub sems dpa'yang sems can thams cad kyi thun mong du gyur pa yin te |ji ltar rgyal po la phan par nye bar gnas pa ltar gdol bu la yang de bzhin te $\mid$ de ltar na byang chub sems dpa'sems can thams cad kyi thun mong du gyur payin no. Cp. Dharmachakra Translation Committee 2019: 1.222. T. 659 (XVI) 255b27-c2: 云何菩 薩一切衆生平等。善男子, 譬如火性於諸衆生悉皆平等, 如於國王及斿陀羅平等 無二。菩薩亦爾。於諸衆生悉皆平等, 如於國王悉作利益, 於屠殺者亦作利益。 是名菩薩於諸衆生皆悉平等. Also T. 489 (XIV) 719b28-c4. 
As a further example of the disdain in which candālas were held, and in a further contrast to some of the more open statements cited earlier, for the Mahāyāna Mahāparinirvāna-mahāsūtra, some persons might claim that " 'Caṇ̂ālas, persons without any sexual organs, persons with two sexual organs, persons with indeterminate sexual organs, or persons whose organs are incomplete, are all permitted to take the tonsure and follow the Buddhist path'This I [= the Buddha] call an exposition of Māra." ${ }^{84}$ Here, alongside those who are physically debarred from ordination for having aberrant sexual organs-a restriction found also in the almost certainly much older monastic codes-we find a restriction on the very admission to the monastic community precisely of the candāla, and furthermore the assertion that to even suggest that candālas should be ordained is to do the work, literally, of the devil. This sūtra prohibition, moreover, is not unique.

\section{Exclusion from Ordination}

While the examples offered above amply demonstrate the types of negative attitudes held toward canda âlas, there is in addition evidence for the official (that is, normative) institutional rejection of those belonging to this and related categories, namely the explicit prohibition against ordination of candāalas, at least in Mūlasarvāstivāda sources. The Vinayasūtra of Guṇaprabha has the following: "Cartwrights, candāalas, pukkasas and their ilk may not be initiated." ${ }^{85}$

84 T 374 (XII) 406a19-21: 旃陀羅子、無根、二根及不定根身根不具, 如是等輩如來悉 聽出家爲道。是名魔説 = Derge mdo sde, nya 113 b3-4: gdol bu dang $\mid$ dbang po med pa dang $\mid$ mtshan gnyis pa dang $\mid$ mtshan ma nges pa dang $\mid$ dbang po ma tshang ba la sogs pa thams cad de bzhin gshegs pas rab tu byung bar gnang ngo zhes smra na de ni bdud kyis bstan pa yin no. Note that this Tibetan translation is based on the Chinese. The version from Sanskrit reads (Habata 2013: 266, §364): gdol pa'i bu dang | ma ning dang | mtshan gnyis pa dang | yan lag nyams pa thams cad rab tu 'byung bar bcom ldan 'das kyis gnang ngo $\|$... zhes zer ba de lta bu ni bdud kyis smras pa'i mdo sde dang 'dul ba yin par rig par bya ste. See also Cabezón 2017: $380-385$. There are a number of interesting references to caṇ̂̄ālas in this sūtra, but since (perhaps out of an overabundance of caution) I am not quite sure of the Indian authenticity of the relevant passages, I refrain for the moment from bringing them into the discussion. However, it is quite possible that they are in fact genuinely Indian, and should in future be taken into account.

85 Ritsukyō 'Shukkeji' Kenkyūkai 2010: 14, with trans. p. 24 (numbering the sūtra 4*; Sankrityayana 1981 \# 149; cp. Bapat and Gokhale 1982: 25.20-23, with the commentary, taking it as sūtra 1.151): na rathakāra-caṇ̣̂āla-pukkasa-tadvidhān pravrājayet (D 4117, 'dul ba, wu 4b7: lham mkhan dang gdol ba dang g.yung po dang de lta bu rab tu dbyung bar mi byao o). The autocommentary reads: rathakāraś carmmakārah | tadvidhān ity abhokșyān | 
That is, such persons are barred from pravrajy $\bar{a}$, the first phase of the twofold ordination process, the initiation. The auto-commentary expands, saying: "Cartwrights [etc. as a category includes] leather-workers. 'Their ilk' refers to persons from whom [monks] may not receive food. That cartwrights and so on are unworthy of ordination (upasampādana) [or the states of?] śrämaneras or śikșamānas is indicated by their being prohibited from initiation. Therefore, for those [types of persons] as well this [stipulation] is a proof of the impossibility [of ordination]." Quite interestingly, the vital indication concerns food. This requires, obviously, further serious study. This Vinayasütra passage is based on a portion of the Kșudrakavastu of the Mūlasarvāstivāda Vinaya, in which we find the following prohibition on the initiation of candālas: ${ }^{86}$

śrāmaṇeratvaśikṣamāṇatopasam̄ādana-m-anarhatvaṁ rathakārādīnāṁ apravrājane nimittam | tasmād āsām api etad akarañyatvasya pratipādanam. Here one might be tempted to think that lham mkhan = carmakära, as in Mhvy $\S 3795$, but the closely following entry $\S 3797$ has rathakāra = shing rta mkhan nam Iham mkhan. See also D 4119, 'dul ba, zhu 24b6-25a1: shing rta byed pa dang $\mid$ tham mkhan dang $\mid$ gdol pa dang $\mid$ g.yung po dang $\mid$ de lta bu rab tu dbyung bar mi bya'o zhes bya ba la $\mid$ shing rta byed pa ni lham mkhan no || de lta bu zhes bya ba ni zan bza' bar mi bya ba ste | dge tshul nyid dang slob pa nyid kyis bsnyen par rdzogs par'os pa ma yin pa nyid shing rta mkhan la sogs pa rnams la rab tu dbyung ba ma yin pa nyid kyi rgyu mtsan no $\|$ de bas na 'di rnams la yang mi bya ba nyid du ston pa'o.

Note that sūtra $6^{*}$ reads na jātikāyaduștam pravrajitam upasthāpayet, followed by the commentary which begins rathakārādikam abhojyaṁ jātiduștam. It continues a bit later tathā ca bhikṣuñā parșaddūșakāparșad na upasthāpayitaryā upasthāpayati sātisāro bhavatīty uktvā kiyatā parșaddūṣakāparșad vaktavyā |jātito varṇnasamisthānena ca $\mid$ katham jātitaḥ | rathakāracaṇ̣̂ālapukkasakulāt | katham varṇnasasthānatah | haridrakeśā ityādy atroktam. This should be considered together with sūtra $4^{*}$, and the Vinaya passage quoted below. This all clearly requires more unpacking than is possible here, both concerning the exact meaning of the texts and the sources upon which they rely. For the purposes of the present study, however, it is clear that initiation, much less ordination, is prohibited to caṇ̂ălas and others belonging to the same general class of persons. I am grateful to Shayne Clarke for his kind advice with regard to these passages.

86 T. 1451 (XXIV) 328b4-11: 是故, 苾媰不應與彼毀法衆人, 而爲出家。若有作者, 得越 法罪。如佛所説。如是等類不與出家。苾芻不知何謂毀法衆人。佛言。有二 種鄙惡, 毀辱法衆。云何爲二。一, 謂種族。二, 謂形相。言種族者, 謂家門族 胄下賤卑微、貧寒庸品、客作自活、飲食不充。或旃茶羅、下羯娑、木作、 竹作、浣衣、酤酒、獵師等類。是名種族鄙惡. D 6, 'dul ba, da 38a2-5: de lta bas na dge slong gis 'khor sun par byed pa'i 'khor nye bar gzhag par mi bya'o || dge slong gis 'khor sun par byed pa'i 'khor nye bar gzhag na'gal tshabs can du 'gyur ro \| bcom ldan 'das kyis dge slong gis 'khor sun par byed pa'i 'khor nye bar gzhag par mi bya'o zhes bka'stsal pa dang $\mid$ dge slong rnams kyis 'khor sun par byed pa ji lta bu ma shes nas | bcom ldan 'das kyis bka' stsal pa $\mid$ dge slong dag 'khor gyis 'khor sun par byed pa ni rgyu gnyis kyis te | gang dag gis shes na rigs dang $\mid$ mtshan mas so $\|$ de la rigs kyis ni rigs gang yang rung bas te | ma rabs | dman pa $\mid$ phongs pa $\mid$ dkos thag pa $\mid$ bkren pa $\mid$ bza' ba dang $\mid$ btung ba chen po mi bdog 
"Therefore [following on a story not quoted here], a monk should not grant initiation to those persons who damage the monastic community (parșaddūșaka). If he does, he becomes guilty of a transgression." The Buddha said: "Such [above mentioned] types of persons may not be granted initiation." The monks did not know what was meant by "persons who damage the monastic community." The Buddha said: "There are two types of persons who are detestable, and damage the monastic community. What are the two? 1. [Those of certain] castes. 2. [Those of certain] physical appearance. ${ }^{87}$ As for [those of certain] castes, this means that their family lineage is low class and mean, impoverished and common, laborers, without enough to eat or drink. Some are candālas, pukkasas, carpenters, bamboo-workers, washer-men, liquor sellers, birders and the like. These are what are called persons who are detestable."

Did Buddhists actually demonstrate such attitudes in their lived practice? Above we noticed the Kaśmīri scholar Bhațta Jayanta speaking of Buddhists eating together with monks from all four castes, and understood this as possible evidence for non-discriminative practices, or perceptions of such among those who disapproved of such behaviors. Referring now not to caste but to outcastes, in the same author's Nyāyamañjarī we find him arguing that Buddhists actually do accept the validity of the Vedic tradition with regard to (some) matters of caste (here $j \bar{a} t i$, birth or class): 88 "Even these wretched Buddhists and their ilk, strictly restrained by the Veda's authority, avoid physical contact with candālas and other persons [of low birth]. For if they really had thrown off the pride of belief in caste, what problem would there be for them in being touched by candāalas and such like?" In other words, put together with the earlier cited

pa de lta bu'i rigs dag las so sor skyes par gyur pa de dag dge slong rnams rab tu 'byin par byed na de lta bu ni rigs kyis yin no. I translate the Chinese here. Something a bit different appears to be going on with the Tibetan, which should be considered also in the context of the Vinayasütra materials, quoted in the previous note.

87 Discussion of this is extremely interesting, but unfortunately cannot be dealt with here. See $\mathrm{n} .85$ and the Vinayasūtra materials there, and sūtras $5^{*}$ and $6^{*}$. This material would richly reward careful attention.

88 ete bauddhādayo 'pi durātmāno vedaprāmānyyaniyamitā eva caṇ̣̂ālādisparśam pariharanti | niraste hijātivādāvalepe kaś candāalādisparśe doṣah, trans. Sanderson (slightly modified), unpublished revised Gonda lecture n. 359; text ed. Kataoka 5.2.2.2. The trans. of Kataoka and Freschi 2012: 38 is slightly different: "[T]hese wicked Buddhists, etc., are disciplined [in their behaviour because of assuming] the validity of the Veda: they avoid the contact of a canda a la, and of other [untouchables]. [This is an evidence of the fact that they also respect the Veda] because once one has refuted the pride in casteism, what is wrong in touching a caṇ̣āla, etc.?" 
passage, Jayanta suggests that even though Kaśmīri Buddhists accepted caste equality in terms of the four castes, eating together with them promiscuously, their (more fundamental?) adherence to generalized norms of Indian society is demonstrated by their maintenance of taboos against candūalas. Once again, of course, we must remember that this passage represents a polemical position, and is not journalistic reporting. That said, we must at least consider the possibility that if the evidence Jayanta's readers would have seen around them would not have corresponded to the picture he painted, his argument would have held little sway.

\section{Grammaticalization of -caṇ̣̂āla}

A final but extremely important category in Buddhist texts is the use of cand $\bar{a}-$ la as a sort of grammatical affix, attached to terms which an author wishes to despise. ${ }^{89}$ Although (as far as I know) we lack evidence from lexicons citing it as the inverse of -ratna as a grammaticalized affix, a well-attested usage which indicates that something is considered the best in its class, ${ }^{90}$ in fact we have a pair of linked passages in the Ariguttaranikāya which show precisely this opposition: ${ }^{11}$

Bhikkhus, possessing five qualities, a lay follower is a canḍāla of a lay follower, a stain of a lay follower (upāsakamala), a despised upāsaka (upāsakapatikițtha). ${ }^{92}$ What five? (1) He is devoid of faith (assaddha); (2) he is immoral (dussïla); (3) he is superstitious and believes in auspicious

89 This may be what Yamazaki 2005: 194 had in mind when he stated "the term 'caṇāan'a' itself was often used as a term of derision."

$90 \quad$ Salvini 2016: 221 quotes as an example Amarakośa 3.3.607: ratnam svajātiśreșthe 'pi.

91 AN iii.206,5-22 (175): pañcahi bhikkhave dhammehi samannāgato upāsako upāsakacaṇ̣̂ālo ca hoti upāsakamalañ ca upāsakapatikuțtho ca | katamehi pañcahi $\mid$ assaddho hoti dussīlo hoti kotūhalamañgaliko hoti mañgalaì pacceti no kammaì ito ca bahiddhā dakkhineyyami gavesati tattha ca pubbakāram karoti| imehi kho bhikkhave pañcahi dhammehi | samannāgato upāsako upāsakacaṇ̃ālo ca hoti upāsakamalañ ca upāsakapatikuțtho ca | pañcahi bhikkhave dhammehi samannāgato upāsako upāsakaratanañ ca hoti upāsakapadumañ ca upāsakapuṇ̃̂rīkañ ca | katamehipañcahi| saddho hoti sïlavā hotiakotūhalamangaliko hoti kammam் pacceti no mañgalam na ito bahiddhä dakkhineyyam gavesati idha ca pubbakāraṁ karoti | imehi kho bhikkhave pañcahi dhammehi samannāgato upāsako upāsakaratanañ ca hoti upāsakapadumañ ca upāsakapuṇdarīkañ cā ti. Trans. Bodhi 2012: 788-789, slightly modified. In the Sumañgalavilāsinī I.235, an upāsaka who is not faithful, moral and is superstitious is called a caṇdāla upāsaka, etc.

See Edgerton 1953, s.v. pratikrsșța and pratikrușța. 
signs (kotūhalamañgalika), not in kamma; (4) he seeks outside here [the Buddhist community] for a person worthy of offerings; and (5) he first does [meritorious] deeds there. Possessing these five qualities, a lay follower is a canḍāla of a lay follower, a stain of a lay follower, the last among lay followers.

Bhikkhus, possessing five qualities, a lay follower is a gem (ratana) of a lay follower, a red lotus of a lay follower, a white lotus of a lay follower. What five? (1) He is endowed with faith; (2) he is virtuous; (3) he is not superstitious and believes in kamma, not in auspicious signs; (4) he does not seek outside here for a person worthy of offerings; and he first does [meritorious] deeds here. Possessing these five qualities, a lay follower is a gem of a lay follower, a red lotus of a lay follower, a white lotus of a lay follower.

Here the author characterizes those who are ultimately anti-Buddhistdenying their faith, their morality, karma and the samgha itself-by labeling them with the polar opposite of -ratana, in other words, with what is evidently the very worst epithet he could conjure up, "candâala."

The same Ariguttaranikāya uses the term further in reference to objectionable brāhmaṇas: ${ }^{93}$ "And how, Doṇa, is a brāhmaṇa a caṇdāla of a brāhmaṇa?"

93 AN iii.228.24 (192): kathañ ca doṇa brāhmaṇo brāhmaṇacaṇdālo hoti. Trans. Bodhi 2012: 805. Peter Bisschop kindly brings to my attention the appearance of the term brähmañacaṇ̂̄āla in Brāhmaṇical sources. Mahābhārata 12.77.8 has the following: āhvāyakā devalakā nakșatragrāmayājakāḥ ete brāhmaṇacaṇ̣̂ālā mahāpathikapañcamāḥ, translated by Sanderson 20oga: 277n658: "All the following are brahmin untouchables: couriers, temple-priests, those who perform worship to the asterisms, those who perform worship on behalf of a whole village, and, fifth, those who undertake long journeys." Sanderson 20oga: $276-277$ locates this by saying: "[F]unctioning as a priest in a temple, and therefore living off the endowment of the deity in return for one's work, carried a loss of status with which the older tradition was unwilling to be associated. According to brahmanical sources any brahmin who persists in such work for three years is considered to have lost his brahmin status and is then known as a Devalaka. He is described as an upabrāhmaṇah 'a sub-brahmin' or, even more disparagingly, as a brāhmaṇacaṇ̂̄ălah 'a brahmin untouchable.'" Shulman 1984: 16 observes the tension for brāhmanas whenever they must, for economic reasons, work in subservient roles, remarking on "the vehemence with which the classical sources inveigh against the Brahmin who seeks his livelihood as a purohita or as the servant of a god (devalaka, 'godling,' in the scornful language of the texts). We are even told that the Brahmin who performs worship for others for a fee is, in effect, a Caṇ̂āala," referring precisely to Mahābhärata 12.77.8. In the context of the priority of marrying a woman of proper caste, in Mānava-Dharmaśāstra 9.87 (ed. and trans. Olivelle 2005: $762,194)$ we find: yas tu tat kārayen mohāt sajātyā sthitayānyayā $\mid$ yathā brāhmañacand̦ălah pürvadrștas tathaiva saḥ, "If he foolishly gets another wife to carry these out while 
The answer includes a lengthy discussion of the brāhmana's practices, including: "He then seeks a teacher's fee for his teacher both in accordance with the Dhamma and contrary to the Dhamma - by agriculture, by trade, by raising cattle, by archery, by service to the king, by a particular craft, and not only by wandering for alms without scorning the alms bowl." ${ }^{44}$ There follows an account of his sexual promiscuity (he has sex with any kind of woman, including a variety of low caste persons), but then the text returns to its theme: ${ }^{55}$ "He earns his living by all kinds of work. Brāhmanas say to him: 'Why, sir, while claiming to be a brāhmana, do you earn your living by all kinds of work?' He answers them: 'Just as fire burns pure things and impure things yet is not thereby defiled, so too, sirs, if a brāhmanna earns his living by all kinds of work, he is not thereby defiled.' Since he earns his living by all kinds of work, this brāhmaṇa is called a caṇdāla of a brāhmaṇa. It is in this way that a brāhmaṇa is a caṇ̣̂ala of a brāhmana."

We find the same grammaticalized usage in Mahāyāna scriptures, in which for instance the Perfection of Wisdom literature disparages those who believe and act wrongly as "bodhisattva-candâalas." As an example, one passage discusses one who dwells in the forest without the proper attitude, giving confused advice to other bodhisattvas. The bad bodhisattva is then characterized in the following terms, with imagery we will encounter again below: ${ }^{96}$

a wife of equal class is available, he becomes exactly like a Brahmin-Cāṇḍāla described by the ancients." [Note that the spelling in Olivelle's trans. does not agree with his own edition!]. It is quite possible that the Buddhists who used the term were aware of such sources, or even precisely these passages.

94 ācariyassa àcariyadhanam pariyesati dhammena pi adhammena pi kasiyā pi vanijjājya pi gorakkhena pi issatthena pi räjaporisena pi sippaññatarena pi kevalam pi [Bodhi 2012: 1743nı19o reads na kevalà̇] bhikkhācariyāya kapālam anatimaññamāno. Trans. Bodhi 2012: 805, but perhaps rather with Hare 1934: 167: "or despising not the beggar's bowl, just by going about for alms."

95 AN iii.229,16-24: so sabbakammehi jīvikam kappeti | tam enam brāhmaṇā evam āhaṁsu kasmā bhavaṁ brāhmaṇo pațijānamāno sabbakammehi jīvikam kappetī ti | so evam āha seyyathā pi bho aggi sucim pi ḍahatiasucim pi dahatina ca tena aggiupalippati| evam evam kho bho sabbakammehi ce pi brāhmaño jīvikam kappeti na ca tena brāhmaṇo upalippati | sabbakammehi jīvikam kappetī ti kho doṇa tasmā brāhmaṇo brāhmanacaṇ̂ālo ti vuccati | evam kho doṇa brāhmaṇo brāhmaṇacaṇdālo hoti. Trans. Bodhi 2012: 805-806.

The Chinese translation T. 26 (158) (I) 68ob22-681c23, esp. 681b23 ff. makes it clear that both work and marriages are not in conformity to the dharma.

96 Aștasāhasrikā (Wogihara 1932-1935: 782.28-783.5) = T. 223 (VIII) 353b26-c1 = T. 224 (VIII) $461 \mathrm{c} 2-8$ = T. 225 (VIII) $499 \mathrm{a} 25-29$ = T. 226 (VIII) 534c3-8 = T. 227 (VIII) 571b3-7 = T. 228 (VIII) 653c3-8). I translate the Sanskrit: ayam subhūte bodhisattvacaṇ̂̄ālo veditavyo bodhisattvadūṣi veditavyo bodhisattvapratirūpako veditavyo bodhisattvaprativarṇiko veditavyo bodhisattvakāraṇdavako veditaryaś cauraḥ śramaṇaveșaṇacauro bodhisattvayāni- 
Subhūti, you should know this one as a candāla of a bodhisattva. You should know him as a defiler of a bodhisattva (bodhisattvadūșin). You should know him as an imitation bodhisattva (bodhisattvapratirūpaka). You should know him as a counterfeit bodhisattva (bodhisattvaprativarnika). You should know him as a chaff bodhisattva (bodhisattvakāraṇda$v a k a$ ). He is a thief wearing the clothing of a śramana. He is a thief of people belonging to the vehicle of the bodhisattvas. He is a thief of the world along with its gods. Such people as these should not be served ( $n a$ sevitavya), should not be worshipped (na bhaktavya) and should not be honored (na paryupāsitarya).

The commentary of Haribhadra on the Aștasāhasrikā informs us that "he is a candāla of a bodhisattva since he is untouchable (asprśya) by other bodhisattvas." 97 A similar passage is also found in the Pañcavimśatisāhasrikāa. ${ }^{98} \mathrm{~A}$ bodhisattva who defends his own corrupt version of the Mahāyāna is compared as follows: "He will revile other good men belonging to the vehicle of the bodhisattvas, he despises them, yells aggressively at them, abuses them. This one, Subhūti, should be known as a caṇ̂ala of a bodhisattva, a defiler of a bodhisattva, a counterfeit bodhisattva, a thief of the world with its gods, men and Asuras, a thief in the guise of a śramana, a thief of good men belonging to the vehicle of the bodhisattvas." Such expressions are apparently formulaic.

kānām pudgalānām cauraḥ sadevakasya lokasya tajjātītah khalu punaḥ subhūte pudgalo na sevitavyo na bhaktaryo na paryupāsitaryah.

97 Wogihara 1932-1935: 783.14: anyair bodhisattvair asprśyatvād bodhisattvacaṇ̣̂āah. According to Yamazaki 2005: 197, the term asprśya "only came into use in the later Dharmaśāstras." This is further specified by Jha 1975: 24, who states "Viṣnu is the first lawgiver to use asprśya," referring to V.104 and XLIV.9. This would date the usage as late as the seventh century. Haribhadra belongs to a time approximately a century or so later (Harter 2019: 204). See also Kashyap 2005, esp. p. 53. Note as well a passage in the Hevajratantra that points to a similar sense, this also chronologically consistent since this text has been dated by Szántó 2015: 334 to around 9oo ce: "Men of all castes may touch as readily as his own body [those difficult to touch, duhsprśa-JAs], dombas, caṇdālas, carmāras, haḍ̂ikas and the rest, brahmans and kṣatriyas, vaiśyas, and śūdras" (trans. Snellgrove 1959: I.98). The text reads (Snellgrove 1959: II.58.21-22, vs. II.iii.45): dombacanḍālacarmārahaḍdikādyān tu duhsprśán | brahmakșatriyavaiśyaśüdrädyān ātmadeham iva sprśet. Note here the key terms duhsprssāan and sprśet.

98 Kimura 1992: 9.24-30: ayaṁ bodhisattvas tadanyān bodhisattvayānikān kulaputrān paṁsayișyaty avamam்syate ullāpayișyati kutsayișyati | ayam subhūte bodhisattvacaṇdālo veditavyaḥ | bodhisattvadūși veditavyaḥ | bodhisattvaprativarṇiko veditavyah | caurah sadevamānușāsurasya lokasya | caurạ̣ śramaṇaveșeṇa | cauro bodhisattvayānikānām kulaputrānāàm. Cp. Conze 1975: 438-439. 
In the Ākāsagarbhasūtra, we find another such grammaticalized use of caṇ̣̂āla, as follows: ${ }^{99}$

In the future, good man, kṣatriyas will have canḍālas of royal priests, candāalas of ministers, and canḍālas of soldiers - very rich and powerful fools who fancy themselves scholars. Seeming to engage in many sorts of meritorious deeds of charity, arrogant and haughty of their generosity, through their arrogance, pride and insolence, they will divide the kșatriyas [from each other?] and the kșatriyas from the renunciants. ${ }^{100}$ Relying on the kṣatriyas, those [candālas-Tib.] will punish the renunciants, stealing their possessions in [the guise of] punishment. Because of that calamity, those monks are forced to surrender to them their personal belongings, the belongings of the local samgha, the belongings of the universal samgha or belongings of the stūpa which were taken by the renunciants. What is more, those candālas will offer them to the kṣatriyas. ${ }^{101}$ Both of these actions constitute root transgressions.

Similarly, the Sūryagarbhasūtra states that:102

99 Bendall 1897-1902: 63.10-16: punar aparam kulaputra bhavișyanty anāgate 'dhvani kṣatri-

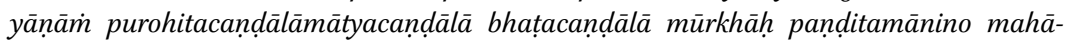
dhanā mahābhogāh | bahuvidheșu dānamayapunyakriyāvastuṣu samidrśyante te tyāgamadamattā mānamadadarpeña kṣatriyam vibhedayanti | śramañān kṣatriyaih | te kṣatriyān niśritya śramaṇān dạ̣dāayanti | artham daṇdena mușanti | tenopadravena te bhikṣavah paudgalikam vā sāmghikam vā cāturdiśasāimghikam vā staupikam vā śramanair apahrtya teșām prāhrtam pradāpyante | te punaś caṇ̣̂ālāh kșatriyasyopanāmayișyanti |te ubhayato 'pi müläpattim āpadyante. D 3940, dbu ma, khi 41a5-b1. The sūtra itself is found at T. 405 (XIII) 653c10-20; D 26o, mdo sde, za 277a7-b3 (the trans. in Sakya Pandita Translation Group 2019: 1.75 is problematic in details).

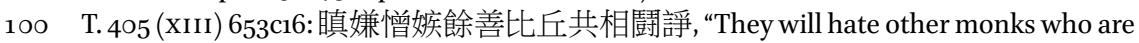
good [unlike themselves], and dispute with them." The Sanskrit may be corrupt here, but the Kanjur text is also difficult to understand.

101 T. 405 (XIII) 653c16-18: 恃王臣力。取善比丘物以奉大臣。大臣得已傳以上王。 佛法僧物亦復如是, “Making use of the authority of the royal ministers, they will take the possessions of the good monks and give them to the ministers. The ministers in their turn will give them to the king. The goods of the Buddha, Dharma and monastic community will also be treated like this."

102 D 257, mdo sde, za, 104b3-7: mi gdol pa gnas na gnas par byed pa ni sla'i | dge slong gdol pa yongs su 'dzin pa dang bcas pa |rgyud tshig pa $\mid$ don la mi lta ba $\mid$ 'jig rten pha rol btang ba $\mid$ snying rje'i bsam pa med pa | phyi sa khung chen po dang 'dra ba | bdud kyi lam du zhugs pa $\mid$ Iha dang mi rnams la gnod pa byed pa $\mid$ dus gsum thams cad kyi drang srong thub pa rnams la slu bar byed pa $\mid$ dkon mchog gsum gyi gdung chos kyi mar me med par byed pa $\mid$ chos kyi rgya mtsho skems par byed pa $\mid$ chos smra bai dbyen byed pa $\mid$ sbyin pa po dang sbyin bdag rnams la 'drid par byed pa $\mid$ dge slong chos kyis gnas pa rnams la tho 'tsham par byed pa $\mid$ 
to be a dweller in the dwelling place of canda a las is easier than living with one in suite with a candāla of a monk, who has an angry character, who does not see the significance [of the Teaching], who has rejected the other world, who is without compassionate intention, who resembles a giant pit of excrement, who has entered the path of Māra, who does injury to gods and men, who deceives all the sages of the three times, who extinguishes the dharma lamp of the descendants of the three jewels, who dries up the ocean of the Teaching, who causes dissension among the preachers of the Teaching, who cheats donors and benefactors, who mocks monks who live according to the Teaching, who interrupts the income of a samgha which is in agreement. That evil monk through the condition of his attachment turns the king away from the path to heaven. He turns away kṣatriyas, brāhmaṇas, vaiśyas, śūdras, men, women, boys and girls. He sends them to the three paths of the evil destinies.

The company that the expressions "candūla of a monk" and "canḍala of a bodhisattva" is made to keep in these passages demonstrates very well its semantic sphere: the authors here are practically spitting with vitriol as they array the most horrible epithets they can think of. A yet again quite similar passage from the Ratnarāsisisutra - perhaps the most extreme we will encounter hereoccurs in a chapter devoted, with incredible venom, to bad monks:103

dge 'dun 'thun par byed pa'i rgyun gcod par byed pa ni de lta ma yin no || sdig pa can gyi dge slong de niyongs su'dzin pa'i rkyen gyis mtho ris kyi lam las rgyal po ldog par byed pa yin no || rgyal rigs dang | bram ze dang | rje'u rigs dang $\mid$ dmangs rigs dang $\mid$ skyes pa dang $\mid$ bud med dang $\mid$ khye'u dang $\mid$ bu mo ldog par byed pa yin no || ngan song gi lam gsum la rab tu gzhog par byed pa yin no. Cp. T. 397 (XIII) 238a9-12.

103 I cite the Tibetan text from my dissertation, Silk 1994, § III.1-5. My translation here does not engage with the philological problems of the passage, which will be dealt with in my forthcoming revision of my edition.

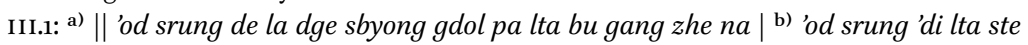
dper na gdol pa ni rtag tu dur khrod spyod yul pa yin te $\left.\right|^{\text {c) }}$ shi ba la re ba dang $\mid$ byams pa med pa'i mig gis 'gro ba la lta ba dang | shi ba la dga' ba yin no || d) 'od srung de bzhin du dge sbyong gdol pa lta bu yang rtag tu mdza' bshes kyi khyim dang | slong ba ster ba'i khyim la gdu ba yin te $\mid$ e) de nas rnyed pa dang $\mid$ bkur stis nye bar 'tsho zhing khyim pa de dag chos sam | 'dul ba yang dag par 'dzin du mi 'jug pa dang | de rnyed pa'i ched du 'dris par byed kyi don gyi ched du ma yin pa dang $\mid$ mdza' ba'i sems med cing rtag tu rnyed pa la re bayin te $\mid$ f) 'od srung 'di ni dge sbyong gdol pa lta bu zhes bya'o \|

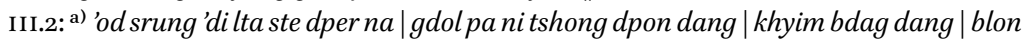
po dang $\mid$ khams kyi rgyal po dag dang $\mid$ bram ze dang $\mid$ rgyal rigs dang $\mid$ grong rdal gyi mi dang $\mid$ yul gyi mi rnams kyis rtag tu yongs su spang bar bya ba'i 'os yin te $\left.\right|^{\text {b) }}$ gdol par rig nas thag ring po bas kyang ring por yongs su spong ngo || ${ }^{c}$ 'od srung de bzhin du dge sbyong gdol pa lta bu yang dge slong dang $\mid$ dge slong ma dang $\mid$ dge bsnyen dang $\mid$ dge bsnyen ma 
What is the candāla of a śramana? The candāla is one who always frequents charnel grounds. He hopes [to find] a corpse, looks at living beings with eyes devoid of friendliness, and takes delight in [encountering] a corpse. In a similar way, the cand $\bar{a}$ la of a śramana also is one who is always eager to find the house of a friend and the house of one who gives alms. Then, subsisting on the profit and honor [he obtains], he does not incite those householders to undertake the Teaching and the Discipline, but he becomes familiar with them for the sake of profit and not for the sake of [acquiring] the goal; he is without a loving heart and he always hopes for profit.

The candăla deserves to be forever spurned by guild-chiefs, householders, ministers, vassal princes, brāhmaṇas, kṣatriyas, townsmen and country-folk. Recognizing the canda âla, even those far away spurn him at a distance. In a similar way, the candāla of a śramana too deserves to be spurned by monks, nuns, upāsakas and upāsikās who uphold the precepts and are virtuous.

High class people do not touch and do not use a candāala's flag or garments, everything used by him. Similarly, because the candāla of a śramana's bowl, robes, and everything used by him is sought for through improper livelihood, sought for through injuring body and mind, those who uphold the precepts and are virtuous do not touch and do not use them.

tshul khrims dang ldan pa | yon tan dang ldan pa rnams kyis yongs su spang bar bya ba'i 'os yin te $\left.\right|^{\text {d) }}$ dge sbyong gdol pa lta bu sdig pa'i chos kun tu spyod cing tshul khrims 'chal par rig nas | thag ring po bas kyang ring por yongs su spong ngo ||

III.3: ') 'od srung 'di lta ste dper na $\mid$ gdol pa'i kha phyis sam | gos sam |yongs su spyad pa de thams cad la ni skye bo ya rabs rnams mi reg cing yongs su mi spyod do $\|$ b) 'od srung de bzhin du dge sbyong gdol pa lta bu'i lhung bzed dam | chos gos sam |yongs su spyad pa de thams cad ni mi mthun pa'i 'tsho bas yongs su btsal ba |c) lus dang sems rmas pas yongs su btsal ba yin pas tshul khrims dang ldan pa | yon tan dang ldan pa dag de la mi reg cing mi spyod do $\|$

III.4: ') 'od srung 'di lta ste dper na |gdol pa ni kha phyis thogs te | zhum zhum por byas nas gzhan gyi khyim du 'gro'o || b) 'od srung de bzhin du dge sbyong gdol pa lta buyang zhum zhum por byas nas | de bzhin gshegs pa'i mchod rten la phyag 'tshal lo || ${ }^{\text {c) }}$ zhum zhum por byas nas 'khor gyi nang du 'gro'o || d) zhum zhum por byas nas gtsug lag khang dang|gnas khang dang | gzhan gyi khyim du 'gro'o || e) zhum zhum por byas nas 'gro ba dang |'dug pa dang | nyal bar byed do || f) 'od srung de ltar na zhum zhum por byas pa sdig pa 'chab pa de'i spyod lam gang yin pa de dag thams cad ni rung ba ma yin pa las yongs su brtags pa'o

III.5: a) 'od srung 'di lta ste dper na | gdol pa'i sems ni bde 'gro'i skye ba la mi gnas so || b) de ci'i phyir zhe na |'di ltar de rang gi las kyi nyes pa'i phyir ro || c) 'od srung de bzhin du dge sbyong gdol pa lta bu'i sems kyang bde 'gror 'gro bar bya ba'i phyir mi gnas shing $\mid$ de'i 'jig rten pha rol rnam par zhigs la $\left.\right|^{\text {d) }}$ de ngan 'gro gsum du gnas par sgrib pa med de $\left.\right|^{e)}$ 'od srung 'di ni dge sbyong gdol pa lta bu zhes bya'o ॥ 
The mind of the candāla is not set on birth in a good destiny. Why? It is through the fault of his very own actions. Similarly, the mind of the candāla of a śramana too is not set on doing the actions necessary to go to a good destiny, and so that other world is lost, and there is no obstacle to his dwelling in the three bad destinies.

In a very similar manner, the Buddhapitakaduhsisilanigraha, a text which has much in common with the Ratnaräsis in terms of its concern with corruption, contains the following in its own quite expansive discussion of the preceptbreaking monk:104

Śāriputra, when those who are honorable, precept-keeping monks see precept-breaking monks in my community, they will avoid them at a

104 D 220: mdo sde, dza 24a3-b3; P 886: mdo, tshu 24a8-b7; sTog 36 mdo, kha 353a3-b4: shä ri'i bu nga'i bstan pa 'di la tshul khrims dang ldan par bkur ba'i dge slong gang yin pa de dag gis | tshul khrims 'chal ba'i dge slong rnams mthong na | rgyang ring po kho nar yongs su spong bar'gyur ro || de ci'i phyir zhe na | shā rii bu 'di ltar tshul khrims 'chal ba'i dge slong rnams kyi lhung bzed dam $\mid$ chos gos gang yin pa de dag dang $\mid$ tshul khrims dang ldan pa'i dge slong rnams kyir'dres na | dug dang 'dres pa lta bur rig par bya'o || shā rii' bu nga ni sbrul gyi ros gang ba 'am | khyi ros gang ba 'am | mi ros gang ba'i sa la spyod lam bzhi po rnams las spyod lam gangyang rung bas gnas par ni sproyi| shā ri'i bu nga ni tshul khrims 'chal pa'i dge slong spyod [P sbyong for slong spyod] pa nyams pa|'tsho ba nyams pa |lta ba nyams pa rnams dang $\mid$ mtshan gcig gam | nyin gcig gam | skad cig gam | tha na se gol gtogs pa tsam yang Ihan cig tu gnas par mi spro'o || de ci'i phyir zhe na $\mid$ shā ri'i bu'di ltar de lta bu'i dge sbyong $[\mathrm{P}$ slong] rnams ni dge sbyong [P slong] tha shal zhes bya'o \| dge sbyong bkren ba zhes bya'o \| dge sbyong phal pa zhes bya'o \| dge sbyong sbun pa zhes bya'o \| dge sbyong rul pa zhes bya'o || dge sbyong dri can zhes bya'o || dge sbyong gi snyigs ma zhes bya'o || dge sbyong gi dri ma zhes bya'o || dge sbyong gdol pa zhes bya'o \|| dge sbyong nyams pa zhes bya'o || dge sbyong sdig can zhes bya'o \| dge sbyong sre da zhes bya'o || 'phags pa'i lam las phyi rol pa zhes bya'o || dge sbyong chu skyar zhes bya'o || dge sbyong sun 'byin pa zhes bya ste | de dag nga'i bstan pa 'di la rab tu byung nas [? read na?] | bsod nams ma yin pa'i phung po mang du 'thob par gyur ro || shā riii bu de dag ni de bzhin gshegs pa'i bstan pa la 'thab khrol ba yin no || shā ri'i bu de dag ni de bzhin gshegs pa'i bstan pa la chom rkun chos sun 'byin pa yin no $\|$ shā rïi bu skyes bu dam pa mayin pa de dag ni tshul'chos pa 'tsho ba lhur len ba |'jig rten gyizang zing gis bkol ba $\mid$ zas dang bgo ba lhur len pa yin no. T. $653(\mathrm{xV})$ 788c1-12: 持戒比丘見此破戒, 即時遠離。何以故。若破戒比丘手所觸物及所受物於持戒者, 則爲毒惡。舍利 弗, 正使三屍臭穢滿地。我能於中行四威儀, 不能與此破戒比丘須皿共住。何以 故。舍利弗, 是爲沙門中卑陃下賤, 爲沙門中朽壞弊惡, 爲沙門中粃糠, 爲沙門中 垢, 爲沙門中濁, 爲沙門中污, 爲沙門中曲, 爲沙門中鹿, 爲沙門中失聖道者。如 是人等於我法中出家求道, 而得重罪。舍利弗, 如是之人於我法中爲是逆賊, 爲 是法賊, 爲是欺註詐僞之人。但求活命貪重衣食。是則名爲世樂奴僕.

There are many other examples, including in texts which may have been composed outside of India; for instance, an example of bad bodhisattvas compared to candāalas is found in the *Upāsakaśilla-sūtra, 優婆塞戒經 (T. 1488 [XXIV] 1046a24-26). 
great distance. Why? Because, Sāriputra, you should know that mixing those bowls and robes of precept-breaking monks with those of preceptkeeping monks is like mixing with poison. Śāriputra, I am willing to dwell in any of the four modes of deportment at a place full of the corpses of snakes, or full of the corpses of dogs, or full of the corpses of humans, but Saariputra, I am not willing to dwell together with preceptbreaking monks of defiled conduct, of defiled livelihood, of defiled view, for even one night, one day, one moment or even one finger snap's instant. Why? Because, Sāriputra, such monks as that I call "vile monks," "sordid śramaṇas," "vulgar śramaṇas," "refuse śramaṇas," "rotten śramaṇas," "stinking śramaṇas," "weed śramaṇas," "defiled śramaṇas," "canḍ̂ala śramaṇas," "impaired śramanaas," "evil śramaṇas," "chaff śramaṇas," "outsiders to the Noble Path," "crane śramanas,"105 "corrupting śramanas," and if they renounce the world in my instruction they will acquire a great mass of sin ("apunya). Sarriputra, they are disputants in the instruction of the Tathāgata. Sāriputra, they are thieves in the instruction of the Tathāgata, they are corrupters of the teaching. Saanriputra, those dishonorable men are deceitful, are most interested in their own livelihood, are enslaved by worldly material possessions, are most concerned with food and clothing.

Such passages and uses of canḍāla as a grammaticalized suffix could be multiplied in the literature. ${ }^{106}$ It is hardly possible to read such passages without viscerally appreciating that for their authors, the term candāala - the most prominent and frequently encountered term common to these passages-is among the harshest, most extreme epithets that they were capable of disgorging. The word, it is probably not wrong to say, is an extremely strong obscenity, ${ }^{107}$ a clear and unambiguous example of which we saw above in the context

\footnotetext{
105 Shayne Clarke convincingly suggests a connection with the "heron ascetic" (baka) mentioned by Bloomfield 1924: 211-212.

106 There is no need to offer a catalogue, but for instance see Buddhapițakaduhśilanigraha T. 653 (xv) 787b16-21, which speaks of the śramana-candāla (沙門斿陀羅).

107 Despite their suggestive titles, neither Masson-Moussaieff 1971 nor Dwivedi 1981 deal with the topic, being devoted rather to sexual references in Sanskrit poetics. Perhaps the closest we can get at present to an examination of insulting words in Sanskrit is Hopkins 1925. To my regret, my ignorance of Russsian leaves Vigasin 2016 largely inaccessible to me (but from what I gather from its machine translation, it seems interesting). More narrowly focusing on Buddhist monastic regulations, one might think of the rules against insulting speech (Pāli omasavāda, Skt. ünamanusyavāda), the best treatment of which so far is probably that of Hirakawa 1994: 66-82.
} 
of the Kuśa Jātaka. ${ }^{108}$ To clarify: the direct targets of the righteous indignation of the authors cited above are monks who do not properly uphold the discipline expected of them, the precept-breaking monks, who are among other things thieves of the donations offered by the pious. The anger of the authors, and their disgust, is directed at those who, they feel, threaten the integrity of the Buddhist monastic community (and its ability to receive support from the surrounding community). But how are we to understand the vocabulary through which these authors express this anger and disgust? For while we may well judge monastic discontent with bad monks to be fully justified, a pertinent question for us is how to make sense of the transfer of this negative feeling to another group: what lies behind the generalized deployment of reference to a despised social class to express disgust?

\section{$8 \quad$ Rhetoric and Prejudice}

To focus our question in a Buddhist frame: how can we account for the fact that Buddhist authors, so obviously concerned with overcoming the multitude of defilements which characterize the human condition, and ultimately with transcendence to a state of perfection beyond prejudice and whim, would nevertheless deploy language indicative of base and unreflective hatred? In other words, if we accept that the diversity of the evidence gathered here cannot be explained by appealing to different lineages and different authors, some of whom were tolerant and some of whom were not - and this would be hard to maintain, in any event, since all the materials equally were enshrined in the canonical literatures of the tradition-how can we make sense of the apparent conflict between, on the one hand, a rhetoric of non-discrimination, and even equality and openness toward all, and, on the other hand, expressions of extreme prejudice and vitriol referencing those belonging to the most vulnerable stratum of society? And this latter question does not disappear even when we recognize that "really" the vitriol is directed against a deserving target, the monks who threaten the integrity of the community. The question, then, is not the direct target, but the indirect reference, the object of the expression used to express disdain.

The ways this vocabulary functions rhetorically and psychologically-its logic, so to speak - are, I think, comparatively easy to understand, and the key lies in the basic human condition. Certainly without wanting to equate the two,

108 See above n. 68. 
it is worth reflecting on the parallelism between this Buddhist rhetoric toward outcastes and the pervasive anti-Jewish rhetoric encountered for centuries in European writing, and beyond. As David Nirenberg (2013: 260) has so clearly shown, the nature of anti-Jewish rhetoric is that it consists in, as he says in speaking of Martin Luther, a "strategic appropriation of the most powerful language of opprobrium available," and that moreover its target is not real, actual Jews anywhere or anytime, but rather the created figurative, imaginary Jew. ${ }^{109}$ I would suggest that very much the same thing might be said of the candāla in Indian Buddhist rhetoric: at least at the extreme, and surely in the grammaticalized usages illustrated above, the canda a $l a$ is not a real individual, nor even a real class of persons, but a fictional and imaginary embodiment of the ultimate negative, the very nth degree of the objectionable and the despicable. ${ }^{110}$ As long as such vitriol is directed toward the purely imaginary—and we might think here also of the deployment of the term hinnayāna in some Mahāyāna polemics - there is perhaps little harm done. Just as no person self-identifies as a hypocrite, so long as no individual or group could be understood as the referent of a slander, its danger is limited. The Indian Buddhist imagery of the candâala, and its deployment, however, arise from the social environment of a very real group of individuals, and the effect of this rhetoric on the treatment of real persons in the real world cannot help but have been corrosive, to say the least. We may not know exactly how this worked itself out in ancient India, but we know well that far on the other side of the Buddhist world, and even into the modern day, the term sendara, the Japanese pronunciation of the Chinese characters used to transcribe cand $\bar{a} l a$, continues to function in Japan as a label with profoundly negative social consequences, applied to the outcastes, the hinin, the non-humans, or eta, those filled with filth, terms nowadays replaced by buraku, but still indicative of a highly discriminated-against class. ${ }^{111}$

Fundamental Buddhist karma doctrine holds that one's present circumstances are merely the result of one's past actions, and there is nothing whatsoever inherent in one's status. This is indeed precisely one of the bases of the

109 This is naturally only reinforced when we recall the anti-semitic imagery rife in England during the period (roughly 13 th-mid-17th c.) when there were no Jews there, or the same in Japan, where even in the present there are no more than a handful of actual Jews, and historically none at all, yet anti-semitic tracts populate the shelves of bookshops.

110 In order to highlight the ease with which one may use terms unaware of their origins or nature, it may not be out of place to relate my own experience with "gyp" as a verb meaning "to cheat." It was only well into middle age that I realized that this was derived from prejudicial attitudes toward gypsies, Roma. It is little solace that I am not alone in this: see Challa 2013, Sonneman 1999.

111 See above n. 3. 
rejection of caste as a meaningful category for the epistemologists, as so ably demonstrated by Eltschinger. Does it make sense, then, to assume that the same individuals (the authors of our texts, almost certainly Buddhist monks) could both sincerely believe in the meaninglessness of any specific and contingent form of birth, and yet use vocabulary which is so blatantly discriminatory and offensive? How can we reconcile doctrine with actions-in this case, at the very least, linguistic usages — which apparently contradict it?

Here research from psychologists interested in prejudice may help us. On the one hand, we learn that " $[\mathrm{F}]$ or those who pursue egalitarian objectives consistently, relatively automatic forms of bias control may emerge and operate in ways that are not especially taxing to the self-regulatory system."112 Put into English, this means that one can train oneself to be less prejudicial. Nevertheless, other research suggests that "mere knowledge of a proposition endorsed by other people can contribute to the activation of corresponding associations in memory even when a person does not believe in the validity of that proposition. For example, mere knowledge of a cultural stereotype may lead to automatic negative reactions toward the members of a disadvantaged minority group even when the stereotype is considered inaccurate."113 If one lives, then, in a society in which certain attitudes are pervasive, one's own convictions may not be able to override one's conditioning. While we do not know nearly enough about the sources of our Indian Buddhist texts, making the assumption that Buddhist literature tells us something of Buddhist culture- that the literature reveals a way of thinking, even if it does not reveal anything concrete about action in the world - we might conclude that at least some Indian Buddhists made sincere and extensive efforts to overcome their pre-judgements, their prejudices, in this case with regard to canda âlas as outsiders and as Other, but it does not follow that all tried to do so, nor that all those who tried were necessarily able to do so consistently. Moreover, the very same collection of evidence also suggests that there were more than a few institutionally embedded Buddhists, monastic authors of texts preserved and treasured by the tradition, who either out of personal conviction or because they were unable to overcome their cultural conditioning, and perhaps even acting subconsciously, expressed themselves in a manner manifestly prejudicial toward specific groups of persons, those whom we refer to generically as outcastes. ${ }^{114}$ In many cases, their

112 Bodenhausen et al., 20og: 128.

113 Gawronski \& Bodenhausen 2006: 695.

114 My colleague Gregory Forgues offers an intriguing suggestion, which requires more detailed consideration than I am able to offer at this moment. (I have slightly reformulated what Forgues wrote to me and added some references; the "I" below is JAS): What if bauddhas were designated as candâlas in brahmanical communities and, as a con- 
very language demonstrates a depth of negative feeling that it is hard to reconcile with the highest aspirations of Buddhist spiritual cultivation. The hypotheses of psychologists suggest that the solution to this paradox may lie precisely in a recognition that these authors were human beings, even if some aspired to be spiritual virtuosi. But a further conclusion is that there remained something in the intellectual processes of some of these authors which did not permit them to notice any contradiction between eloquent advocacy of, for instance, the bodhisattva path toward self-perfection and the salvation of all beings and use of vile, noxious and hateful rhetoric referencing a sub-category of that same group of beings.

Were some Indian Buddhists, then, at least tolerant of candāalas, even if they did not accept them as equals? At least for some scholars, "a minimal definition of tolerance requires that three events should occur: that someone should take offence at something, that he should be in a position to suppress it, and he should choose to forbear from using this power. People who do not take offence at anything, therefore, can be tolerant no more than they can be intol-

sequence, ended up stressing the Otherness of candālas in their own texts to preserve their identity as followers of the Buddha? One can imagine that, if Buddhist communities were associated with candālas by some non-Buddhists, bauddhas might have intentionally drawn a line between themselves and those social groups that were associated with things they could not identify with (such as a livelihood based on some kind of violence). Sanderson 2015: 163 (clearly directly inspired by Kane 1968-1977: II.1: 168-169 IV. 114-115) cites two verses which, among other things, put Buddhists into the category of a type of untouchable. The first Sanderson attributes to Aparāditya's Yãjñavalkyasmrtițīkā (the text is also called Aparārka-Yajñavalkyadharmaśāstranibandha, and some refer to the author as Aparārka; see Kane 1968-1977: I.2: 713-723), but this figure belongs to the 12th c. (see also Sanderson's note 2015: 163-164n19). Sanderson cites Aparāditya's quotation of a Șațtrimśanmata (which I cannot further identify) as follows: "If he comes into physical contact with Buddhists, Pāśupatas, materialists, deniers [of life after death, the validity of the Veda, and the like], or brahmins engaged in improper employment, he should bathe fully clothed." He further gives another citation of the same author: "If he sees Jainas, Pāśupatas, Buddhists, Kāla[mukha]s, [Śākta] Kaulas, or peripatetic [mendicants] he should glance at the sun. If he has come into contact with any of them he should bathe fully clothed." From such references, it seems that brahmanical communities may have associated with caṇ̂a ạlas all those who did not fit into their religious/social worldview. Beyond the purely linguistic prejudiced-based usage of the expression caṇdăla, it would be interesting to research whether bauddhas might have used this term in a way that reflects social considerations resulting from the solidification of the caste system. One consideration in any further discussion is the date of the texts noticed by Kane and subsequently by Sanderson; the sources we have at present are rather late (12th c.), and therefore unlikely to have been significant in terms of Indian Buddhist history; however, if Aparāditya really is citing significantly older sources, these would require careful consideration. (Note that Hazra 1940: 201 cites precisely the same sources; evidently both he and Sanderson based themselves on Kane, though neither acknowledges it.) 
erant."115 Ideally, then, keeping in mind one category of passages introduced above, we may conclude that the attitude toward candālas advocated by some Indian Buddhist writers is one of neither tolerance nor intolerance, but simply non-offense. Further, it might be possible, with charity, to conclude that for other authors, what comes through is both their utter disdain for canda âlas, and their sense that they are powerless to do anything about it, at least if we interpret the vehemence, if not the violence, of their words as an expression of their frustration at their powerlessness.

"A just society," it has been said, "is one in which persons value the well-being of their fellow citizens." 116 A prerequisite for this, of course, is a recognition that others are indeed one's fellows. This, it seems to me, may be an awareness missing in much of the rhetoric we encounter in regard to candāalas in Indian Buddhist literature. And it is precisely this disconnection between different aspects of Buddhist thinking that is, I believe, well deserving of our attention.

\section{Reference Note}

References to Pāli follow the abbreviations of the Critical Pâli Dictionary.

Tibetan canonical sources are cited from the Derge Kanjur and Tanjur, indicated with D, unless otherwise noted.

When no translator is noted, the English renderings are my own.

\section{Acknowledgments}

This work was supported by the European Research Council (ERC) under the Horizon 2020 program (Advanced Grant agreement No. 741884). Some of the research for this study was carried out several years ago under the auspices of a VICI grant from the NWo (Nederlandse Organisatie voor Wetenschappelijk Onderzoek, Project number 277-63-001, 2010-2015) for the project "Buddhism and Social Justice," which I directed at Leiden University. I remain grateful for the generous support. I thank Peter Szántó, Vincent Eltschinger, Rafal Felbur, Gregory Forgues, Shayne Clarke, Jens-Uwe Hartmann, Peter Bisschop, Harunaga Isaacson, and two reviewers for the journal, for very kind and helpful comments on various drafts. I further thank Ven. Vinìtā Tseng for her generosity in sharing with me passages from her edition of the Ratnameghasūtra, now in preparation, as well as several corrections.

\footnotetext{
115 Vernon and LaSelva 1984: 4

116 Kelly 2003: 267 .
} 


\section{References}

Aktor, Mikael. 2002. "Rules of untouchability in ancient and medieval law books: Householders, competence and inauspiciousness." International Journal of Hindu Studies 6.3: 243-274.

Aktor, Mikael. 2008. Ritualisation and Segregation:The untouchability complex in Indian Dharma literature with special reference to Parāśrasmr̊ti and Parmāśramādhavīya. Corpus Iuris Sanscriticum et fontes iuris Asiae Meridianae et Centralis 9 (Torino: Comitato Corpus Iuris Sanscriticum et fontes iuris Asiae Meridianae et Centralis). Aktor, Mikael. 2010. "Untouchability." In K.A. Jacobsen, et al., eds., Brill's Encyclopedia of Hinduism: Sacred Texts, Ritual Traditions, Arts, Concepts. Vol. II. (Leiden: Brill): 876881.

Aktor, Mikael. 2016. "The Cāṇ̣ālī as Śakti: Untouchable Women in Some Tantric Texts." In Bjarne Wernicke Olesen, ed., Goddess Traditions in Tantric Hinduism: History, Practice and Doctrine. (London: Routledge): 96-108.

Alsdorf, Ludwig. 1974. "The Impious Brahman and the Pious Caṇ̂āa." In Lance Cousins et al. eds., Buddhist Studies in Honour of I.B. Horner (Dordrecht: D. Reidel): 913 .

Aoyama Tōru 青山亨 1982. “Śārdūlakarṇāvadāna no kenkyū” Śārdūlakarṇāvadānaの研 究. Indogaku Bukkyōgaku Kenkyū 印度学仏教学研究 30.2: 152-153.

Bapat, P.V, and V.V. Gokhale. 1982. Vinaya-sūtra. Tibetan Sanskrit Works Series 22 (Patna: Kashi Prasad Jayaswal Research Institute).

Barua, P.L. 1959. “The Doctrine of Caste in Early Buddhism." Journal of the Asiatic Society of Pakistan 4: 134-156.

Bayer, Achim. 2010. The Theory of Karman in the Abhidharmasamuccaya. Studia Philologica Buddhica, Monograph 26 (Tokyo: The International Institute for Buddhist Studies).

Bendall, Cecil. 1897-1902. Çikshāsamuccaya: A Compendium of Buddhistic Teaching Compiled by Çāntideva, Chiefly from Earlier Mahāyāna-sūtras. Bibliotheca Buddhica 1 (St. Pétersbourg: Imperial Academy. Reprint: Osnabrück, Biblio Verlag, 1970).

Bhattacharya, Vidhushekhara. 1957. The Yogācārabhūmi of Ācārya Asañga: The Sanksrit Text Compared with the Tibetan Version (Calcutta: The University of Calcutta).

Bloomfield, Maurice. 1924. "On False Ascetics and Nuns in Hindu Fiction." Journal of the American Oriental Society 44.3: 202-242.

Bodenhausen, Galen V., Andrew R. Todd, and Jennifer A. Richeson. 20o9. "Controlling Prejudice and Stereotyping: Antecedents, Mechanisms, and Contexts." In T. Nelson, ed., Handbook of Prejudice, Stereotyping, and Discrimination (New York: Psychology Press): 111-135.

Bodhi, Bhikkhu. 200o. The Connected Discourses of the Buddha: A Translation of the Samyutta Nikāya (Boston: Wisdom Publications). 
Bodhi, Bhikkhu. 2012. The Numerical Discourses of the Buddha: A Translation of the Añguttara Nikāya (Boston: Wisdom Publications).

Bodhi, Bhikkhu. 2017. The Suttanipāta: An Ancient Collection of the Buddha's Discourses, together with its commentaries (Boston: Wisdom Publications).

Bodiford, William. 1996. "Zen and the Art of Religious Prejudice: Efforts to Reform a Tradition of Social Discrimination." Japanese Journal of Religious Studies 23.1/2: 1-27.

Bronkhorst, Johannes. Forthcoming. "India's Past Reconsidered." To appear in Paul W. Kroll and Jonathan A. Silk, eds., "At the Shores of the Sky": Asian Studies for Albert Hoffstädt (Leiden: Brill).

Cabezón, José Ignacio. 2017. Sexuality in Classical South Asian Buddhism (Boston: Wisdom Publications).

Challa, Janaki. 2013. "Why Being 'Gypped' Hurts The Roma More Than It Hurts You.” Found at https://text.npr.org/s.php?sId=242429836, dated December 30, 2013.

Chalmers, Robert. 1894. "The Madhura Sutta concerning Caste." Journal of the Royal Asiatic Society 1894: 341-366.

Chang, Garma C.C., et al. 1983. A Treasury of Mahāyāna Sūtras: Selections from the Mahāratnakūța Sūtra (University Park and London: The Pennsylvania State University Press).

Choong, Mun-keat. 20o9. "A comparison of the Pāli and Chinese versions of the Brāhmanna Samyutta, a collection of early Buddhist discourses on the priestly Brāhmanas." Journal of the Royal Asiatic Society, Series 3, 19.3: 371-382.

Chopra, Tilak Raj. 1966. The Kuśa-Jātaka: A Critical and Comparative Study. Alt- und Neu-Indische Studien 13 (Hamburg: Cram, de Gruyter \& Co).

Conze, Edward. 1962. The Gilgit Manuscript of the Așțādaśasāhasrikāprajñāpāramitā: Chapters 55 to 70, Corresponding to the 5th Abhisamaya. Serie orientale Roma 26 (Rome: Instituto Italian per il Medio ed Estremo Oriente).

Conze, Edward. 1975. The Larger Sutra on Perfect Wisdom, with the divisions of the Abhisamayālañkāra (Berkeley: University of California Press).

Cowell, E[dward] B[yles] and R[obert] A[lexander] Neil. 1886. The Divyāvadāna: A Collection of Early Buddhist Legends (Cambridge; Reprint: Amsterdam: Oriental Press / Philo Press, 1970).

Davidson, Ronald M. 2017. "Magicians, Sorcerers and Witches: Considering Pretantric, Non-sectarian Sources of Tantric Practices." Religions (Special Issue on Society for Tantric Studies) 8(9), 188: 1-33.

Dezső, Csaba. 2005. Much Ado About Religion by Bhațta Jayanta. Clay Sanskrit Library. (New York: New York University Press).

Dharmachakra Translation Committee. 2019. The Jewel Cloud. v. 1.30.1. Published online by 8400o: Translating the Words of the Buddha.

Dwivedi, R.C. 1981. "Concept of Obscenity (aślīlatā) in Sanskrit Poetics." Annals of the Bhandarkar Oriental Research Institute 62.1/4: 67-76. 
Edgerton, Franklin. 1953. Buddhist Hybrid Sanskrit Dictionary (New Haven: Yale University Press).

Ellis, Gabriel. 2019. "Early Buddhism and Caste." Rocznik Orientalistyczny 72.1: 5571.

Eltschinger, Vincent. 2012. Caste and Buddhist Philosophy: Continuity of Some Buddhist Arguments against the Realist Interpretation of Social Denominations. Trans. Raynald Prévèreau (Delhi: Motilal Banarsidass).

Eltschinger, Vincent. 2017. "The Yogācārabhūmi against Allodoxies (paravāda): 3. The Caste-Classes," in Christophe Vielle, Christian Cannuyer and Dylan Esler, eds., Dieux, génies, anges et démons dans les cultures orientales \& Florilegium Indiae Orientalis Jean-Marie Verpoorten in honorem. Acta Orientalia Belgica 3o. Brussels: Société Royale Belge d'Études Orientales: 203-240.

Feer, Henri-Léon. 1901. "Le Karma-Çataka." Journal Asiatique (January-February 19o1) 53-100; (March-April 1901): 257-315; (May-June 1901): 410-486.

Fick, Richard. 1920. The Social Organisation of North-East India in Buddha's Time. Trans. Shishirkumar Maitra (Calcutta. Reprint: Delhi: Indological Book House, 1972).

Fukita, Takamichi. 2003. The Mahāvadānasūtra: A New Edition Based on Manuscripts Discovered in Northern Turkestan. Sanskrit-Wörterbuch der buddhistischen Texte aus den Turfan-Funden, Beiheft 10 (Göttingen: Vandenhoeck \& Ruprecht).

Fujita Kōtatsu 藤田宏達. 1953. “Genshi Bukkyō ni okeru shishō byōdōron” 原始仏教に おける四姓平等論. Indogaku Bukkyōgaku Kenkyū 印度学仏教学研究 2.1: 55-61.

Gawronski, B., \& Bodenhausen, G.V. 2006. "Associative and propositional processes in evaluation: An integrative review of implicit and explicit attitude change." Psychological Bulletin 132: 692-731.

Goodman, Charles. 2016. The Training Anthology of Śāntideva: A Translation of the Śikṣa-samuccaya (New York: Oxford University Press).

Habata, Hiromi. 2013. A Critical Edition of the Tibetan Translation of the Mahāparinirvāṇa-mahāsūtra. Contributions to Tibetan Studies 10 (Wiesbaden: Dr. Ludwig Reichert Verlag).

Hanumanthan, K[rishnaswamy] R[anaganathan]. 1979. Untouchability: a historical study upto 1500A.D.: with special reference to Tamil Nadu (Madurai: Koodal Publishers).

Hare, Edward M[iles]. 1934. The Book of the Gradual Sayings III (Reprint London: Pali Text Society, 1973).

Harrison, Paul, Jens-Uwe Hartmann, and Kazunobu Matsuda. 2016. "The Final Folio of a Version of the Larger Sukhāvatīvyūhasūtra and Fragments of a Text Possibly Related to the Tathāgatabimbaparivarta." In Jens Braarvig, ed., Manuscripts in the Schøyen Collection: Buddhist Manuscripts IV (Oslo: Hermes): 283-293.

Harter, Pierre-Julien. 2019. "Haribhadra." In Jonathan A. Silk, ed. Brill's Encyclopedia of Buddhism. II: Lives (Leiden: Brill): 204-208. 
Hayashi Hisayoshi 林久良. 1997. Bukkyō ni miru sabetsu no genryū: Sendara: Etori hōshi no gogen 仏教にみる差别の根源: 旃陀羅一餌取法師の語源 (Tokyo: Akashi shoten 明石書店).

Hazra, Rajendra Chandra. 1940. Studies in the Purānic Records on Hindu Rites and Customs. Dhaka: The University of Dacca (University of Dacca Bulletin 20).

Hirakawa Akira 平川彰. 1994. Nihyakugojūkai no Kenkyū 二百五十戒の研究 III. Hirakawa Akira Chosakushū 平川彰著作集 16 (Tokyo: Shunjūsha 春秋社).

Hirakawa Akira 平川彰. 200o. Ritsuzō no Kenkyū 律蔵の研究 II. Hirakawa Akira Chosakushū 平川彰著作集 10 (Tokyo: Shunjūsha 春秋社).

Hiraoka Satoshi 平岡聡. 1991. "Diviya-avadāna ni mirareru shakaiteki chii to shukke no mondai”ディヴィヤ・アヴァダーナに見られる社会的地位と出家の問題. Nanto Bukkyō 南都仏教 65: 19-37.

Hiraoka Satoshi 平岡聡 2002. Setsuwa no kōkogaku: Indo Bukkyō setsuwa ni himerareta shiso 説話の考古学: インド仏教説話に秘められた思想 (Tokyo: Daizō shuppan 大 蔵出版).

Hiraoka Satoshi 平岡聡. 2007a. Budda no nazo toku sanze no monogatari: Diviya Avadāna zen'yaku ブッダが謎解く三世の物語『ディヴィヤ・アヴァダーナ』全訳 (Tokyo: Daizō shuppan).

Hiraoka Satoshi 平岡聡. 2007b. “Shutsuyōkyō no seiritsu ni kansuru mondai” 出曜経の 成立に関する問題. Indogaku Bukkyōgaku kenkyu 印度学仏教学研究 55.2: 181-187 $(848-842)$.

Hokazono Kōichi 外園幸一. 1994. Raritavisutara no Kenkyū (Jōkan) ラリタヴィスタ ラの研究 (上巻) (Tokyo: Daitō Shuppansha 大東出版社).

Hopkins, E. Washburn. 1925. “Words of Defamation in Sanskrit Legal Language." Journal of the American Oriental Society 45: 39-50.

Horner, Isaline Blew. 1938-1966. The Book of the Discipline (Vinaya Pitaka) (London: The Pali Text Society. Reprint 1982-1986). 6 volumes.

Huber, Édouard. 1908. Sûtrâlaṃkâra. Traduit en Français sur la version chinoise de Kumârajîva (Paris: Ernest Leroux).

Isobe Yumi 磯邊友美. 2005. “Śārdūlakarṇāvadāna ni miru chandāra no shukke” Saārdūlakarṇāvadānaに見るチャンダーラの出家. Ryūkoku daigaku daigakuin bungaku $k e n k y u \bar{u} k a$ kiyo 龍谷大学大学院文学研究科紀要 27: 17-31.

Jamison, Stephanie W. 20o9. "Sociolinguistic Remarks on the Indo-Iranian *-ka-Suffix: A Marker of Colloquial Register." Indo-Iranian Journal 52.2-3: 311-329.

Jansen, Berthe. 2014. "Selection at the Gate: Access to the Monkhood and Social Mobility in Traditional Tibet." In Tsuguhito Takeuchi et al., eds., Current Issues and Progress in Tibetan Studies: Proceedings of the Third International Seminar of Young Tibetologists, Kobe 2012 (= Journal of Research Institute 51), Kobe: Kobe City University of Foreign Studies: $137-164$.

Jha, Vivekanand. 1974a. "From Tribe to Untouchable: The Case of Niṣādas." In R.S. Shar- 
ma, ed., Indian Society: Historical Probings in Memory of D.D. Kosambi (New Delhi: Peoples Publishing House): 67-84.

Jha, Vivekanand. 1974b. "Status of the Rathakāra in Early Indian History." Journal of Indian History 52.1: 39-47.

Jha, V.N. 1975. "Stages in the History of Untouchability." Indian Historial Review 2.1:14-31. Jha, Vivekanand. 1978. "Position and Status of Bamboo-workers and Basket-makers in Ancient and Early Medieval Times." Proceedings of the Indian History Congress 39.1: 230-240.

Jha, Vivekanand. 1979. "Leather Workers in Ancient and Early Medieval India." Proceedings of the Indian History Congress 40: 99-108.

Jha, V.N. 1986. "Caṇ̣āla and the Origin of Untouchability." Indian Historial Review 13.1-2: $1-36$.

Jha, Vivekanand. 1997. "Caste, Untouchability and Social Justice: Early North Indian Perspective." Social Scientist 25.11/12: 19-30.

Jones, J[ohn] J[ames]. 1949-1956. The Mahåvastu (Reprint: London: Pali Text Society, 1973-1978).

de Jong, Jan W. 1988. "Buddhism and the Equality of the Four Castes." Hommages et Opera 12: 423-431.

Kane, P[andurang] V[aman]. 1968-1977. History of Dharmaśāstra (Ancient and Medieval Religious and Civil Law in India). Second Edition. Government Oriental Series B 6 (Poona: Bhandarkar Oriental Research Institute).

Karashima, Seishi. 2003. "A Trilingual Edition of the Lotus Sutra: New editions of the Sanskrit, Tibetan and Chinese versions." Annual Report of The International Research Institute for Advanced Buddhology at Soka University 6: 85-182.

Karashima, Seishi, and Margarita I. Vorobyova-Desyatovskaya. 2015. Buddhist Manuscripts from Central Asia. The St. Petersburg Sanskrit Fragments I. Tokyo: The Institute of Oriental Manuscripts of the Russian Academy of Sciences and The International Research Institute for Advanced Buddhology, Soka University.

Kashyap, Shashi. 2005. "Cāṇ̣āla (the only untouchable by birth in Dharma-śāstra)." Bhāratīya Vidyā 65: 49-64.

Kataoka, Kei. No Date. Edition of Nyāyamañjarī Āgamaprāmāṇyam. http://www2.lit .kyushu-u.ac.jp/ kkataoka/Kataoka/NMaprR.pdf

Kataoka, Kei, and Elisa Freschi. 2012. "Jayanta on the validity of sacred texts (other than the Veda)." Minami Ajia Kotengaku 南アジア古典学 / South Asian Classical Studies 7:1-55.

Kelly, Erin I. 2003. Review of Hans Oberdiek, Tolerance: Between Forbearance and Acceptance. Lanham, Md.: Rowman and Littlefield, 2001. The Philosophical Review 112/2: 266-269.

Kimura, Takayasu. 1986. Pañcavimiśatisāhasrikā Prajñāpāramitā II-III (Tokyo: Sankibō Busshorin Publishing). 
Kimura, Takayasu. 199o. Pañcavimśatisāhasrikā Prajñāpāramitā IV (Tokyo: Sankibō Busshorin Publishing).

Kimura, Takayasu. 1992. Pañcavimśatisāhasrikā Prajñāpāramitā V (Tokyo: Sankibō Busshorin Publishing).

Krishan, Y. 1986. "Buddhism and the Caste System." Journal of the International Association of Buddhist Studies 9.1: 71-83.

Kudo, Noriyuki. 2004. The Karmavibhanga:Transliterations and Annotations of the Original Sanskrit Manuscripts from Nepal. Bibliotheca Philologica et Philosophica Buddhica 7 (Tokyo: The International Research Institute for Advanced Buddhology, Soka University).

Kuijper, F.B.J. 1991. Aryans in the Rigveda. Leiden Studies in Indo-European 1 (Amsterdam: Rodopi).

Kusama Hōshō 草間法照. 1989. “Indo Bukkyō ni okeru byōdō to sabestu: sono shintai shōgaishakan o megutte” インド仏教における平等と差別: その身体障害者観をめ ぐつて. In Fujita Kōtatsu hakase kanreki kinen ronshū kankōkai 藤田宏達博士還暦 記念論集刊行会, eds., Indo testugaku to Bukkyō: Fujita Kōtatsu hakase kanreki kinen ronshū イン ド哲学と仏教: 藤田宏達博士還暦記念論集 (Kyoto: Heirakuji shoten 平楽寺書店): 275-295.

Lamotte, Étienne Paul Marie. 1944-1980. Le Traité de la grande Vertu de Sagesse. Publications de l'Institut Orientaliste de Louvain 25, 26, 2, 12, 24 (Louvain: Université de Louvain; reprint, 1970-1981).

Lamotte, Étienne Paul Marie. 1976. The Teaching of Vimalakīrti (Vimalakīrtinirdeśa). Trans. Sara Boin (London: The Pali Text Society).

Law, Bimala Churn. 1937. Concepts of Buddhism (Amsterdam: H.J. Paris / Kern Institute, Leiden).

Lefmann, Salomon. 1902-19o8. Lalita Vistara: Leben und Lehre des Çākya-Buddha (Halle: Verlag der Buchhandlung des Waisenhauses; reprint: Tokyo: Meicho-Fukyūkai, 1977).

Lévi, Sylvain. 1932. Mahākarmavibhañga (La Grande Classification des Actes) et Karmavibhañgopadeśa (Discussion sur le Mahā Karmavibhañga). (Paris: Librarier Ernest Leroux).

Levman, Bryan Geoffrey. 2013. "Cultural Remnants of the Indigenous Peoples in the Buddhist Scriptures." Buddhist Studies Review 30.2: 145-180.

Loukota Sanclemente, Diego. 2019. The Goods that Cannot Be Stolen: Mercantile Faith in Kumāralāta's Garland of Examples Adorned by Poetic Fancy. PhD thesis, UCLA.

Lozang Jamspal and Kaia Tara Fischer. 2020. The Hundred Deeds (Karmaśataka). Version v 1.1.3. Online publication by 8400o: Translating the Words of the Buddha.

Maetani Eshō (Akira) 前谷恵紹(彰). 1994. “Mătañga no shuzokuteki kigen o megutte” Măttanga の種族的起源をめぐつて. Mikkyō Bunka 密教文化 184: 156-131.

Maetani Eshō (Akira) 前谷恵紹(彰). 1995. “Chandārī, Mātangī ni tsuite no kaishaku: 
arataru shiten yori” チャンダーリー・マータンギーについての解釈: 新たなる視 点より. Kōyasan daigaku ronsōo 高野山大学論叢 30: 1-30.

Marciniak, Katarzyna. 2019. The Mahāvastu: A New Edition. Vol. III. Bibliotheca Philologica et Philosophica Buddhica XIV,1 (Tokyo: The International Research Institute for Advanced Buddhology Soka University).

Masson-Moussaieff, J. 1971. "Obscenity in Sanskrit Literature." Mahfil 7.3/4: 197-207.

Matsunaga, Yūkei 松長有慶. 1978. The Guhyasamāja Tantra (Tokyo: Toho Shuppan).

Matsunaga Yūkei 松長有慶. 1991. “Indo Mikkyō ni okeru sendarakan” イン ド密教に おける旃陀羅観. Kōyasan daigaku mikkyō bunka kenkyūjo kiyō 高野山大学密教文 化研究所紀要 4: 1-20. Reprinted in Matsunaga Yūkei chosakushū II: Indo Mikkyō $n o k \bar{z} z \bar{o}$ 松長有慶著作集 第二巻 イン ド密教の構造 (Kyoto: Hōzōkan 法蔵館, 1998): 269-295.

Matsunami Seitatsu 松涛誠達. 1992. “Shukkeshugyōsha to chandāa” 出家修行者とチ ヤンダーラ. Bukkyōgaku 仏教学 32:1-22.

Miyasaka Yūshō 宮坂宥勝. 1976. “Mātanga to Bukkyō” MĀTAN்GA と仏教. In Okuda Jiō sensei kiju kinen ronbunshū kankōkai 奥田慈応先生喜寿記念論文集刊行会, eds., Bukkyō shisō ronshū: Okuda Jiō sensei kiju kinen 仏教思想論集: 奥田慈応先生喜寿 記念 (Kyoto: Heirakuji shoten 平楽寺書店): 1001-1016. [Not seen]

Miyasaka Yūshō 宮坂宥勝. 1991. “Sendara: Bukkyō ni misuterareta mono” 旃陀羅一仏 教に見捨てられたもの. Bukkyō 仏教 / Kikan Bukkyō 季刊仏教 15: 62-70. Reprinted in Miyasaka 1995b: 67-79. I cite the latter.

Miyasaka Yūshō 宮坂宥勝. 1992. “Sendara no shiteki kōsatsu 1" 旃陀羅の史的考察 (一). Chisan Gakuhō 智山学報 55: 37-57. Reprinted in Miyasaka 1995b: 8o-103. I cite the latter.

Miyasaka Yūshō 宮坂宥勝. 1993. “Sendara no shiteki kōsatsu 2" 旃陀羅の史的考察 (二). Chisan Gakuhō 智山学報 56: 71-87. Reprinted in Miyasaka 1995b: 104-122. I cite the latter.

Miyasaka Yūshō 宮坂宥勝. 1994، “Sendara no shiteki kōsatsu 3” 斿陀羅の史的考察 (三). Chisan Gakuhō 智山学報 57: 53-79. Reprinted in Miyasaka 1995b: 123-153. I cite the latter.

Miyasaka Yūshō 宮坂宥勝. 1995a. “Kodai Indo ni okeru chyandāra” 古代インドにおけ るチャンダーラ. Chisan Gakuhō 智山学報 58:19-36.

Miyasaka Yūshō 宮坂宥勝. 1995b. Indogaku Mikkyōgaku Ronkō インド学密教学論考 (Kyoto: Hōzōkan 法藏館).

Mukhopadhyaya, Sujitkumar. 1954. The Śārdūlakarnāvadāna (Santiniketan: Viśvabharati).

Mukhopadhyaya, Sujitkumar. 1963. The Aśokāvadāna (New Delhi: Sahitya Akademi). Ñānamoli, Bhikkhu, edited and revised by Bhikkhu Bodhi. 1995. The Middle Length Discourses of the Buddha: A New Translation of the Majjhima Nikāya (Boston: Wisdom Publications). 
Nanjio, Bunyiu. 1923. The Laìkāvatāra Sūtra. Bibliotheca Otaniensis 1 (Reprint: Kyoto: Otani University Press, 1956).

Nattier, Jan. 2003. A Few Good Men: The Bodhisattva Path according to The Inquiry of Ugra (Ugrapariprcchā) (Honolulu: University of Hawai'i Press).

Nirenberg, David. 2013. Anti-Judaism: The Western Tradition (New York: W.W. Norton \& Company).

Norman, K[enneth] R[oy]. 1958. "Samprasāraṇa in Middle Indo-Aryan." Journal of the Royal Asiatic Society 9o.1-2: 44-5o.

Norman, K[enneth] R[oy]. 1969. The Elders'Verses I:Theragāthā. Pali Text Society Translation Series 38 (London: Pali Text Society. Reprint 1990).

Norman, K[enneth] R[oy]. 1992. The Group of Discourses (Sutta-Nipāta). Volume II: Revised Translation with Introduction and Notes. Pali Text Society Translation Series 45 (Oxford: The Pali Text Society).

Olivelle, Patrick. 1998. The Early Upanișads: Annotated Text and Translation (New York: Oxford University Press).

Olivelle, Patrick. 2005. Manu's Code of Law: A Critical Edition and Translation of the Mānava-Dharmaśāstra (New York: Oxford University Press).

Ōta Shinkai 太田心海. 200o. “Sendara to Bukkyō” 斿陀羅と仏教. In Yamada Meiji 山田 明爾, ed., Yamada Meiji Kyōju Kanreki Kinen Ronbunshū: Sekai Bunka to Bukkyō 山田 明爾教授還暦記念論文集: 世界文化と仏教 (Kyoto: Nagata Bunshōdō 永田文昌堂): 3-26.

Parasher, Aloka. 1979. "The Designation Mleccha for Foreigners in Early India." Proceedings of the Indian History Congress 40: 109-120.

Parasher-Sen, Aloka. 2006. "Naming and Social Exclusion: The Outcaste and the Outsider." In Patrick Olivelle, ed., Between the Empires: Society in India 3oobce to 400 ce (New York: Oxford University Press): 415-455.

Ratchaneekorn Ratchatakorntrakoon and Suchitra Chongstitvatana. 2018. "The Concept of Justice in Buddhism: A Case Study of Caṇāala in Jātakațțakathā." International Journal of Engineering \& Technology 7 (4.38): 970-974.

Rhys Davids, [Caroline Augusta Foley]. 1913. Psalms of the Early Buddhists. II. Psalms of the Bretheren (Reprint: London: Pali Text Society, 1980).

Ritsukyō 'Shukkeji' Kenkyūkai『律経』「出家事」研究会, ed. 2010. “Ritsukyō 'Shukkeji' no kenkyū (6)” 『律経』「出家事」の研究 (6). Sōgō Bukkyō Kenkyūjo nenpō 綜合佛教研究所年報 32:1-37 (48-84). (I have access only to an offprint and cite its pagination.)

Sakya Pandita Translation Group. 2019. The Ākāśagarbha Sūtra. v 2.18. Published online by 84000 : Translating the Words of the Buddha.

Salvini, Mattia. 2016. "Ratna: A Buddhist World of Precious Things." In Fabrizio M. Ferrari and Thomas W.O. Dähnhardt, eds., Soulless Matter, Seats of Energy: Metals, Gems and Minerals in South Asian Traditions (Sheffield: Equinox). 
Samuels, Jeffrey. 2007. "Buddhism and Caste in India and Sri Lanka." Religion Compass 1.1: $120-130$.

Sanderson, Alexis. 20o9a. "The Śaiva Age." In Shingo Einoo, ed., Genesis and Development of Tantrism. Institute of Oriental Culture Special Series 23 (Tokyo: University of Tokyo): 41-349.

Sanderson, Alexis. 20ogb. “Tantric Śaivism and Caste.” Handout for lecture at Institut für Südasien-, Tibet- und Buddhismuskunde Universität Wien 7 June, 20og. 12pp.

Sanderson, Alexis. 2015. "Tolerance, Exclusivity, Inclusivity, and Persecution in Indian Religion During the Early Mediaeval Period." In John Makinson, ed., Honoris Causa: Essays in Honour of Aveek Sarkar. London: Allen Lane, 2015: 155-224.

Sankrityayana, Rahula. 1981. Vinayasūtra of Bhadanta Gunaprabha. Singhi Jain Śāstra Śiksāpītha [sic] Singhi Jain Series 74 (Bombay: Bharatiya Vidya Bhavan).

Schopen, Gregory. 2018. "On Monks and Emergencies: The Brahmanical Principle of Āpad in a Buddhist Monastic Code." In Lutz Edzard, Jens W. Borgland and Ute Hüsken, eds., Reading Slowly: A Festschrift for Jens E. Braarvig (Wiesbaden: Harrassowitz Verlag): 375-391.

Schuessler, Axel. 20o9. Minimal Old Chinese and Later Han Chinese. A Companion to Grammata Serica Recensa (Honolulu: University of Hawai'i Press).

Shimoda Masahiro 下田正弘. 1991. “Genshi Nehangyō no sonzai: Daijō Nehangyō no seiritsushiteki kenkyū: sono ichi” 『原始涅槃經』の存在・『大乗涅槃經』の 成立史的研究その 1 Tōyō Bunka Kenkyūjo Kiyō 東洋文化研究所紀要 103: 1-126.

Shizuka Haruki 静春樹. 2001. "Baramon to inu to chandāra: Han-kāsuto no kyōshoku girei toshite no jurin” バラモンと犬とチャンダーラ: 反カーストの共食儀礼とし ての聚輪. Indogaku Bukkyōgaku Kenkyū 印度学仏教学研究 50.1: 309-307.

Shulman, David. 1984. "The Enemy Within: Idealism and Dissent in South Indian Hinduism." In S.N. Eisenstadt, Reuven Kahane, and David Shulman, eds., Orthodoxy, Hetrodoxy and Dissent in India. Religion and Society 23 (Berlin: Mouton): 11-55.

Silk, Jonathan A. 1994. The Origins and Early History of the Mahāratnakūța Tradition of Mahāyāna Buddhism with a Study of the Ratnarāśi Sūtra and Related Materials. Dissertation, The University of Michigan.

Silk, Jonathan A. 2001. "The Place of the Lotus Sūtra in Indian Buddhism." Journal of Oriental Philosophy 11: 89-107.

Silk, Jonathan A. 2008. "Incestuous Ancestries: On the Family Origins of Gautama Siddhārtha, Interpretations of Genesis 20.12, and the Status of Scripture in Buddhism." History of Religions 47/4: 253-281.

Skilling, Peter, and Saerji. 2014. "How the Buddhas of the Fortunate Aeon First Aspired to Awakening: The pürva-praṇidhānas of Buddhas 1-250." Annual Report of the International Research Institute for Advanced Buddhology at Soka University 17: 245-291.

Skilling, Peter, and Saerji. 2016. "How the Buddhas of the Fortunate Aeon First Aspired to Awakening: The pürva-pranidhānas of Buddhas 251-50o." Annual Report of the 
International Research Institute for Advanced Buddhology at Soka University 19: 149192.

Skilling, Peter, and Saerji. 2017. "How the Buddhas of the Fortunate Aeon First Aspired to Awakening: The pürva-pranidhānas of Buddhas 501-75o." Annual Report of the International Research Institute for Advanced Buddhology at Soka University 20: 167204.

Skilling, Peter, and Saerji. 2018. "How the Buddhas of the Fortunate Aeon First Aspired to Awakening: The pūrva-praṇidhānas of Buddhas 751-994." Annual Report of the International Research Institute for Advanced Buddhology at Soka University 21: 209244.

Snellgrove, David L. 1959. The Hevajra Tantra: A Critical Study. London Oriental Series 6 (London: Oxford University Press).

Sonneman, Toby F. 1999. "Dark Mysterious Wanderers: The Migrating Metaphor of the Gypsy." Journal of Popular Culture 32.4: 119-139.

Speyer, Jacob Samuel. 19o6-19o9. Avadānaçataka: A Century of Edifying Tales Belonging to the Hīnayāna. Bibliotheca Buddhica 3. Indo-Iranian Reprints 3 (St. Petersburg; Reprint: The Hauge: Mouton, 1958).

Śrāvakabhūmi Study Group of Taishō University (Taishō Daigaku Shōmonji Kenkyūkai 大正大学声聞地研究会). 1998. Yugaron Shōmonji:Dai-ichi Yugasho: Sansukuritto-go Tekisuto to Wayaku 瑜伽論声聞地第一瑜伽処: サンスクリット語テキストと和訳 / Śrāvakabhūmi: Revised Sanskrit Text and Japanese Translation: The First Chapter. Taishō Daigaku Sōgō Bukkyō Kenkyūjo Kenkyū Sōsho 大正大学総合仏教研究所研 究叢書 4 (Tokyo: Sankibō Busshorin 三喜房佛書林).

Śrāvakabhūmi Study Group of Taishō University (Taishō Daigaku Shōmonji Kenkyūkai 大正大学声聞地研究会). 2007. Yugaron Shōmonji: Dai-ni Yugasho: Sansukuritto-go Tekisuto to Wayaku 瑜伽論声聞地第一瑜伽処: サンスクリット語テキストと和訳 /Śrāvakabhūmi: Revised Sanskrit Text and Japanese Translation: The Second Chapter. Taishō Daigaku Sōgō Bukkyō Kenkyūjo Kenkyū Sōsho 大正大学総合仏教研究所研 究叢書 18 (Tokyo: Sankibō Busshorin 三喜房佛書林).

Szántō, Péter-Dániel. 2012. Selected Chapters from the Catuspiṭhatantra:(1/2) Introductory study with the annotated translation of selected chapters. $\mathrm{PhD}$ thesis, Oxford University.

Szántō, Péter-Dániel. 2015. "Hevajratantra." In Jonathan A. Silk, ed. Brill's Encyclopedia of Buddhism. I: Literature and Languages (Leiden: Brill): 334-340.

Tatia, Nathmal. 1976. Abhidharmasamuccaya-Bhāsyam. Tibetan Sanskrit Works Series 17 (Patna: Kasahi Prasad Jayaswal Research Institute).

Thieme, Paul. 1994. "On M. Mayrhofer's Etymologisches Wörterbuch des Altindoarischen." Bulletin of the School of Oriental and African Studies 57.2: 321-328.

Turner, R[alph] L[illy]. 1966. A Comparative Dictionary of the Indo-Aryan Languages (London: Oxford University Press). 
Ujike Kakushō 氏家覚勝.1984. “Hakushiki sendara” 博識旃陀羅. Bukkyōgaku kaihō 仏 教学会報 10: 1-6.

Ujike Kakushō 氏家覚勝. 1985. "Bukkyō kyōten ni okeru sendara no yōrei (oboegaki)" 仏教経典における旃陀羅の用例(覚え書). Kōyasan daigaku ronsō 高野山大学論叢 20: 103-146.

Vernon, Richard and Samuel V. LaSelva. 1984. "Justifying Tolerance." Canadian Journal of Political Science / Revue canadienne de science politique 17/1: pp. 3-23.

Vigasin, Alexey A. 2016. "Verbal Abuse and Obscenity in Ancient India", Vestnik drevnei istorii 76/1: 108-117. In Russian: Вигасин А. А. Поношение и срамословие в Древней Индии // Вестник древней истории.

Vollmer, Klaus. 1994. “Die Begriffswelt des Marginalen im mittelalterlichen Japan: Zum Problem der Klassifizierung gesellschaftlicher Randgruppen und ihrer Bezeichnungen." Oriens Extremus 37.1: 5-44.

Yamazaki, Genichi. 2005. The Structure of Ancient Indian Society: Theory and Reality of the Varna System. Toyo Bunko Research Library 6 (Tokyo: The Toyo Bunko).

Yinshun 印順. 1954. Yi fofa yanjiu fofa 以佛法研究佛法. Xinzhu, Taiwan: Zhengwen chubanshe 正聞出版社. Accessed through светA Y16noo16, without indication of the edition used; the page numbers cited thus refer to those in the светA data. 